\title{
Coastal Zone Wind Energy: Part III: A Procedure to Determine the Wind Power Potential of the Coastal Zone
}

M. Garstang

R. A. Pielke

J. W. Snow

March 1982

Prepared for

Pacific Northwest Laboratory

Under Agreement B-93492-Q

Pacific Northwest Laboratory

Operated for the U.S. Department of Energy

by Battelle Memorial Institute 


\title{
DISCLAIMER
}

This report was prepared as an account of work sponsored by an agency of the United States Government. Neither the United States Government nor any agency thereof, nor any of their employees, makes any warranty, express or implied, or assumes any legal liability or responsibility for the accuracy, completeness, or usefulness of any information, apparatus, product, or process disclosed, or represents that its use would not infringe privately owned rights. Reference herein to any specific commercial product, process, or service by trade name, trademark, manufacturer, or otherwise, does not necessarily constitute or imply its endorsement, recommendation, or favoring by the United States Government or any agency thereof. The views and opinions of authors expressed herein do not necessarily state or reflect those of the United States Government or any agency thereof.

\author{
PACIFIC NORTHWEST LABORATORY \\ operated by \\ BATTELLE \\ for the \\ UNITED STATES DEPARTMENT OF ENERGY \\ under Contract DE-AC06-76RLO 1830
}

\begin{tabular}{|c|c|}
\hline \multirow{2}{*}{\multicolumn{2}{|c|}{ Printed in the United States of America }} \\
\hline Available from & \\
\hline \multirow{4}{*}{\multicolumn{2}{|c|}{$\begin{array}{c}\text { National Technical Information Service } \\
\text { United States Department of Commerce } \\
5285 \text { Port Royal Road } \\
\text { Springfield, Virginia } 22151\end{array}$}} \\
\hline & \\
\hline & \\
\hline & \\
\hline \multirow{2}{*}{\multicolumn{2}{|c|}{$\begin{array}{l}\text { NTIS Price Codes } \\
\text { Microfiche A01 }\end{array}$}} \\
\hline & \\
\hline \multicolumn{2}{|c|}{ Printed Copy } \\
\hline & Price \\
\hline Pages & Codes \\
\hline $001-025$ & $A 02$ \\
\hline 026-050 & $\mathrm{A} 03$ \\
\hline 051-075 & A04 \\
\hline $076-100$ & A05 \\
\hline $101-125$ & $\mathrm{~A} 06$ \\
\hline $126-150$ & $\mathrm{~A} 07$ \\
\hline $151-175$ & $A 08$ \\
\hline $176-200$ & $\mathrm{~A} 09$ \\
\hline $201-225$ & A010 \\
\hline $226-250$ & A011 \\
\hline $251-275$ & A012 \\
\hline $276-300$ & $A 013$ \\
\hline
\end{tabular}


COASTAL ZONE WIND ENERGY:

PART III: A PROCEDURE TO DETERMINE THE

WIND POWER POTENTIAL OF THE COASTAL ZONE

Michael Garstang

Roger Pielke

Joseph W. Snow

University of Virginia

Department of Environmental Sciences

Charlottesville, Virginia 22903

March 1982

Prepared for

Pacific Northwest Laboratory

Richland, washington 99352

Under Agreement B-93492-Q of

Prime Contract DE-AC06-76RLO 1830

With the Department of Energy

Office of Solar Power Applications

Wind Energy Technology Division

Pacific Northwest Laboratory

Richland, Washington 99352 
A stepwise procedure is presented for determining the seasonal and/or annual mean potential power density for any location on the East and Gulf coasts of the United States. The steps include reference to the dominant wind regimes and mean power densities already obtained to estimate the wind power potential of the location under consideration; methods to calculate the potential wind power distributions and steps to be taken to locate the best site in the area of interest. The method can be best applied where the atmospheric systems which produce most of the wind energy at the surface are relatively persistent. The method is least successful in areas where the wind field is highly variable. Application of the complete method requires the use of an existing twoor three-dimensional mesoscale numerical model. 
EXECUTIVE SUMMARY $\ldots \ldots \ldots \ldots \ldots \ldots \ldots \ldots \ldots \ldots \ldots \ldots \ldots \ldots \ldots \ldots \ldots \ldots$

TABLE OF CONTENTS .............................. i i

LIST OF TABLES................................

LIST OF FIGURES ................................ iv

1. INTRODUCTION.............................

2. STEPWISE PROCEDURE FOR DETERMINING WIND ENERGY POTENTIAL FOR AN EAST AND GULF COAST LOCATION.................. 3

3. REFERENCES ................................. 7

APPENDIX I: SKILL OF THE MODEL..................... 27

APPENDIX 2: DEFINITION OF WEATHER CATEGORIES.............. 32

APPENDIX 3: MODEL PARAMETERS....................... 36

APPENDIX 4: NORMALIZING THE POWER ESTIMATES.............. 41 
Page

TABLE 1: Occurrence of weather categories in each of the seven (7) coastal regions............ 8

TABLE 2: Mean annual power density ( $\left.\mathrm{w} \mathrm{m}^{-2}\right)$ for the layer $10-100 \mathrm{~m}$ shown for each $100 \mathrm{~km}^{2}(10$ $\mathrm{km}$ north-south $\times 10 \mathrm{~km}$ east-west) for each grid area corresponding to: a) Chesapeake Bay, Figure 3a; b) Apalachee Bay, Figure $3 \mathrm{~b}$; c) South Texas Coast, Figure 3c....... 16

TABLE 3: Coastal stations used in the verification of $100 \mathrm{~m}$ layer-mean annual average power density......................... 20

TABLE 3.A.: Required measurements and parameters to initialize the $2-$ or $3-$ D models........... 38 
FIGURE 1: Regional demarcations of coastal zone and seven representative stations.............. 21

FIGURE 2: Location of test regions: $C B$ - Chesapeake Bay; AB - Apalachee Bay; ST - South Texas coast. Annual average wind speed $\left(\mathrm{m} \mathrm{s}^{-1}\right)$ normalized to $10 \mathrm{~m}$ above the ground for 36 coastal loca-

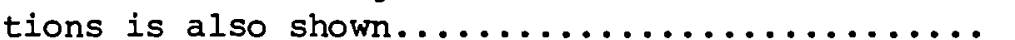

FIGURE 3: Mean annual power density $\left(\mathrm{w} \mathrm{m}^{-2}\right)$ for the layer $10-100 \mathrm{~m}$ for each of the test regions shown in Figure 2. Centers of relative maximum (X) and minimum (N) are indicated along with solid isolines drawn at $50 \mathrm{~W} \mathrm{~m}^{-2}$ intervals. Values of mean annual power density for each $10 \times 10 \mathrm{~km}$ grid area can be obtained by referring grid location to Table 2: a) Chesapeake Bay; b) Apalachee Bay and c) South Texas coast......................... 23

FIGURE 1.A.: Scatter diagram of the cube of measured wind speed, $\mathrm{U}_{\mathrm{m}}{ }^{3}$, versus predicted wind speed, $\mathrm{U}_{\mathrm{p}}$,

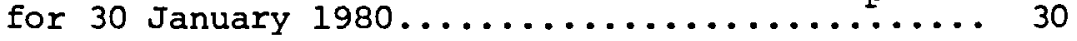

FIGURE 1.B.: Scatter diagram of the cube of measured wind speed, $\mathrm{U}_{\mathrm{m}}{ }^{3}$, versus predicted wind speed, $\mathrm{U}_{\mathrm{p}}$,

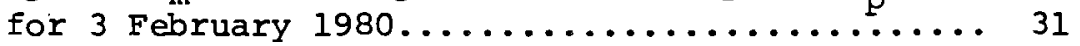

FIGURE 2.A.: The observed synoptic weather map over the United States for 9 January 1964, along with the typing of particular weather feature characteristics. 


\section{INTRODUCTION}

The procedure for determining the wind power potential of a coastal location outlined in this report is designed to provide

*an estimate of the potential wind power of a given coastal region, and

* the location of areas as small as $10 \times 10 \mathrm{~km}$ of maximum (and minimum) wind power potential.

The method cannot locate a specific site within the $10 \times 10 \mathrm{~km}$ grid element. Final site determination must be based upon actual measurements which should also be used to verify the predicted power.

Previous research (Garstang et al., 1980a, 1980b) provides the foundation for the methodology which follows. The underlying principles are that the wind at a point is a function of:

*the large scale global circulation where the relative location of the point of interest to such large scale features as the polar front and jet stream and the semi-permanent surface high pressure systems is important,

*the frequency and duration of instabilities imbedded in the large scale circulation fields such as frontal cyclones,

* the interaction between the larger scales of motion in the atmosphere and the local surface conditions which may convert potential to kinetic energy and transfer, in a systematic manner, the kinetic energy of the free atmosphere downward towards the surface.

The juxtaposition of land and sea at the coastline provides conditions where atmospheric density gradients may be concentrated, potential energy converted to kinetic energy and through the land-sea breeze circulation, transfer the kinetic energy of the deeper atmosphere in a persistent fashion to the surface.

Thus, the wind energy potential of the coastal zone is considered to be dependent on the type and frequency of occurrence of the atmospheric systems. Knowledge of the distribution in time and space of the atmospheric systems leads to a procedure which will allow:

*height corrections to be made to existing wind records,

*an estimate of annual and seasonal power density as a function of atmospheric system, 
*a determination of the potential power density as a function of atmospheric systems,

*identification of the dominant power-producing conditions,

*the interaction between the local coastal conditions and the large scale atmosphere which can be determined for the dominant power-producing conditions, and, finally,

*the determination of regions of maximum and minimum power density potential over the coastal region.

The final product is a distribution of annual potential power density every $10 \mathrm{~km}$ over a domain of $300 \times 300 \mathrm{~km}$. The procedure is applicable to coastlines with little or no topography such as the Gulf and East coasts of the United States where the method was developed.

The method works best where the dominant energy-producing regimes of the atmosphere, such as the outbreaks of cold air behind a cold front, persist for a number of consecutive days. The method performs poorly where, for whatever reason, the meteorological conditions are changing rapidly with time. In most regions rapidly changing weather conditions occupy only a small percent of the total annual cycle. As such, the impact of the changing conditions, which would be ignored by the method, on the wind energy potential is small and can be safely omitted. In some locations, for example the Texas south coast, topography combines with the coastal effects to produce a daily imbalance of forces. This imbalance is translated, in the atmosphere, into a situation which is continually adjusting in an attempt to achieve a balance. Under these circumstances the estimates of the wind power potential are poor. We refer the interested reader to a separate publication (Garstang and Snow, 1981) which presents the results of tests of the methods described below.

In the steps described below the objective is to identify the important meteorological regimes (on a storm or synoptic scale) which govern the wind energy potential of the area or location of interest on the coast. Once the important meteorological regimes and their statistical distribution throughout the year are identified, the large scale atmospheric conditions (wind, temperature, pressure at the surface and with height) can be specified. Knowledge of the large scale atmospheric conditions allows one to specify the starting conditions for a threedimensional mesoscale numerical model. This model (described in detail by Pielke, 1974, and its application to wind energy described by snow, 1981), simulates the interaction between the large-scale atmospheric fields and the mesoscale influences of the region of interest, yielding wind speeds and wind directions at many heights $(e . g .10 \mathrm{~m}, 50 \mathrm{~m}, 100 \mathrm{~m}$, etc. which are chosen by the user) and at grid points spaced $10 \mathrm{~km}$ apart in a 300 by $300 \mathrm{~km}$ domain. The value of the method resides largely in 
the fact that a large number of wind values are generated over the entire region of interest. The information generated by the model greatly exceeds any available observations of the wind. This is particularly true over the open ocean close to the coastline and is mostly true on the mainland coast and offshore islands. The wind power potential may be assessed from the model-produced wind fields and the detailed horizontal distribution of wind speed can be examined to determine the possible optimum locations for power conversion.

The usefulness of the detailed model-predicted wind fields is predicated upon the degree to which these predictions represent the real winds. Appendix 1 provides, from the sources specified above, a summary of the skill of the model and some of the results where the model has been tested against observations. In the sections which follow we provide a step-by-step description of how this method can be applied to the East and Gulf coasts of the Unitted States.

2. STEPWISE PROCEDURE FOR DETERMINING WIND

ENERGY POTENTIAL FOR AN EAST AND GULF COAST LOCATION

Step 1:

Locate the point or area of interest in the appropriate region as designated in Figure 1.

\section{Step 2:}

For the region identified in step 1, look up the frequency distribution of weather categories ${ }^{l}$ in Table la-g. Note the dominant weather category(s) by season and for the annual cycle. Between 1 and 3 categories should account for $75 \%$ or more of the mean annual potential power density $\left(\mathrm{W} \mathrm{m}^{-2}\right)$. For example, for Region I (Table la) Categories II, III and IV contribute 82.658 of the annual power at $50 \mathrm{~m}$. In winter, however, Category III (behind the cold front) contributes more than half (55.07\%) of the power although it occurs only $40.06 \%$ of the time.

\section{Step 3:}

Decide whether, for the application under consideration, the magnitude and seasonal distribution of potential power density is adequate or not. Note that (a) potential power density is listed in Table 1. The potential power available in each region must be modified to reflect the hub-height of the wind turbine(s) being considered by the user.

1

Appendix 2 defines each of the five weather categories listed in Table 1. 
(b) Since the purpose of the subsequent steps is to determine the optimum wind power locations, the optimum power density can be substantially greater (up to 3 times) than the power density values provided for guidance in Table 1 .

If the decision by the user in Step 3 is that either adequate wind power potential exists or is likely to exist then proceed to Step 4 .

Step 4:

Note the geographical location of the point or area of interest relative to the three coastal test regions shown in Figure 2 and in detail in Figures $3 a, b$ and $c$.

If you are dealing with a point which falls in one of the test regions shown in Figures $3 a, b$ and $c$, simply determine the annual potential power density by reading the value nearest your site by locating the appropriate grid element on Figure 3 and reading the annual potential power for that grid element from Table 2.

If you are dealing with an area which falls in one of the test regions, locate the grid element $(10 \times 10 \mathrm{~km})$ in your area which has the highest annual potential power.

If your point or area falls outside of one of the test regions intercept the likely annual power density by examining the adjacent test region(s) and making a qualitative interpolation. For example, if your area of interest is on the Louisiana offshore island, then your annual power density is likely to be similar to that of western Apalachee Bay (Figure $3 b$ ). There would be some confidence in this interpolation whereas if your area lay on the South Carolina coast you would, by reference to the Chesapeake Bay test region (Figure $3 a$ ), have to be cautious as to the potential power density.

Confidence in the interpolation of the first example lies in the fact that the meteorological regimes and, therefore, the region as depicted in Figure 1 , is the same for the Louisiana offshore island as for test region $A B$. In contrast, the second example crosses boundaries between regions from any two of the test sites. Thus one would not be justified in assuming similar wind conditions to either test region $C B$ or test region $A B$.

On the basis of the above steps decide whether the annual potential power density is likely to be locally enhanced or diminished for your area of interest. Where your area falls in a test region this should be an easy decision and if positive you can proceed to step 6 .

If your area falls outside of the test areas but still looks promising proceed to step 5 which is designed to provide the same information as is available in the test regions. 
Depending upon the complexity of the coastline in your area, i.e., no major embayments or estuaries versus a region of marked coastal indentations, you may proceed with 2-D or 3-D model calculations. Computer programs and documentation which will allow the running of either the 2-D or 3-D models are available (at a nominal cost of providing tape, copying and shipping) from the U.Va. and probably from other users of the University of Virginia mesoscale model. The 2-D model can be run at most computer facilities. The 3-D model in the complex form as used by us, can be run at the National Center for Atmospheric Research, Boulder, Colorado. A simplified version of the 3-D model could be run at other computer facilities. Assistance in simplifying the 3-D model can be provided by the U.Va. Wind Energy group.

a) 2-D Calculations: Choose a line normal to the coastline that intersects the point or points which are of greatest interest to you. From Step 2 above, designate the major weather categories.

From local climatology and vegetation determine the input variables for the models for the dominant weather categories. The input variables and other model parameters required are listed in Appendix 3. Run the 2-D model for the dominant weather categories and determine the annual potential power density by following the methods outlined in Appendix 4.

b) 3-D Calculations: Choose the model domain $(300 \times 300 \mathrm{~km})$ to include your area or point of interest. Include any alternative areas or sites in the domain. Determine the input variables as specified in Appendix 3. Run the 3-D calculations for the dominant weather categories and determine the annual potential power density by following the methods outlined in Appendix 4.

The numerical model results will provide an assessment of the local enhancement for your area. A decision can now be made as to the probable optimum location within $5 \mathrm{~km}$ on a line normal to the coastline or within a grid element of $10 \times 10 \mathrm{~km}$. The next step is the final site selection and check on the model estimates.

Step 6:

Site selection and verification: A minimum of two fixed anemometers (at $10 \mathrm{~m}$ ) and a series of profile measurements made from different locations is recommended. One anemometer $(A-1)$ should be chosen at the probable wind generator site. The other anemometer $(A-2)$ should be located on a line intersecting the site or bisecting the grid element in the direction of the greatest predicted gradient in potential power density. $A-2$ should be $5 \mathrm{~km}(2-D$ case) to $10 \mathrm{~km}$ (3-D case) from $A-1$. For intermediate $(100-500 \mathrm{~kW})$ and large $(>500 \mathrm{~kW})$ WECS, soundings are recommended to a height of 1 rotor diameter above the projected rotor 
height. (Thus for a 100-ft rotor mounted at a hub height of $100 \mathrm{ft}$, soundings should be made to $250 \mathrm{ft.l}$ The soundings should be taken at the anemometer sites and at locations between the anemometers with a spacial resolution of not greater than $1 \mathrm{~km}$. Observations from the fixed anemometers and from the mobile sounding system should be made for a period during each of the dominant weather categories. Observations are continued until a valid statistical sample of each dominant synoptic regime is obtained. Normally this should not require more than 6 months over an annual cycle (1 year).

The observations at the anemometer sites are compared with the model predicted observations and the wind distribution along the line or in the grid element is confirmed with the model-predicted distribution. Both the magnitude and the horizontal distributions of the predicted and observed wind must be compared. The model-predicted field should be adjusted to fit the observations.

\section{Step 7:}

Optimum potential power densities can now be calculated and the final decision on the wind machine location can be made. 


\section{REFERENCES}

Garstang, M., S. Nnaji and R. Pielke. 1980a. Coastal Zone Wind Energy, Part I. Synoptic and mesoscale controls and distribution of coastal wind energy. DOE/ET/20274-77/78/79-7. Available from NTIS, Springfield, Virginia.

Garstang, M., R. Pielke and J.W. Snow. 1980b. Coastal Zone Wind Energy, Part I. Potential wind power density fields based on 3-D model simulations of the dominant wind regimes for three East and Gulf coast areas. PNL-3905, Pacific Northwest Laboratory, Richland, Washington.

Garstang, M. and J.W. Snow. 1981. A Comparison of Model Predicted to Observed winds in the Coastal Zone. PNL-3714, Pacific Northwest Laboratory, Richland, Washington.

Pielke, R. 1974. A Three-Dimensional Model of the Seabreeze Over South Florida. Mon. Wea. Rev., 102, 115-139.

Snow, J.w. 1981. Wind Power Assessment Along the Atlantic and Gulf Coasts of the United States. Ph.D. dissertation, Department of Environmental Sciences, University of Virginia, Charlottesville, virginia. 
TABLE 1. Occurrence of weather categories in each of the 7 coastal regions (Figure 1) for representative stations showing the percent of occurrence of each category, the average power and percent of power at $10 \mathrm{~m}$ and $50 \mathrm{~m}$ for each season and for the year for each category. 
TABLE 1a. Region I, representative station: Portland, ME

\begin{tabular}{|c|c|c|c|c|c|c|}
\hline & $\begin{array}{l}\text { Weather } \\
\text { Category }\end{array}$ & $\begin{array}{l}\text { Occurrence } \\
\text { of Category }\end{array}$ & $\begin{array}{c}1 \\
\text { Average } \\
\text { Power } \\
W m^{-2} \\
\end{array}$ & $\begin{array}{c}\text { meters } \\
\text { Contribution } \\
\text { to Power }\end{array}$ & $\begin{array}{c}\text { Average } \\
\text { Power } \\
W \mathrm{~m}^{-2} \\
\end{array}$ & $\begin{array}{l}\text { ters } \\
\text { Contribution } \\
\text { to Power }\end{array}$ \\
\hline Spring & $\begin{array}{r}\text { I } \\
\text { II } \\
\text { III } \\
\text { IV } \\
\text { V }\end{array}$ & $\begin{array}{r}13.59 \\
13.83 \\
31.88 \\
37.89 \\
1.95\end{array}$ & $\begin{array}{r}93.9 \\
74.8 \\
106.2 \\
79.8 \\
103.9\end{array}$ & $\begin{array}{r}14.03 \\
11.59 \\
37.95 \\
33.89 \\
2.27\end{array}$ & $\begin{array}{l}318.7 \\
250.3 \\
224.3 \\
187.1 \\
330.1\end{array}$ & $\begin{array}{r}19.10 \\
15.27 \\
31.53 \\
31.26 \\
2.84\end{array}$ \\
\hline Summer & $\begin{array}{r}\text { I } \\
\text { II } \\
\text { III } \\
\text { IV } \\
\text { V }\end{array}$ & $\begin{array}{r}20.91 \\
9.28 \\
27.31 \\
35.63 \\
4.04\end{array}$ & $\begin{array}{l}62.8 \\
41.2 \\
69.3 \\
51.7 \\
38.8\end{array}$ & $\begin{array}{r}23.50 \\
6.84 \\
33.88 \\
32.97 \\
2.81\end{array}$ & $\begin{array}{l}212.4 \\
140.5 \\
146.1 \\
116.0 \\
134.6\end{array}$ & $\begin{array}{r}30.82 \\
9.05 \\
27.69 \\
28.68 \\
3.77\end{array}$ \\
\hline Fall & $\begin{array}{r}\text { I } \\
\text { II } \\
\text { III } \\
\text { IV } \\
\text { V }\end{array}$ & $\begin{array}{r}12.88 \\
8.88 \\
26.63 \\
46.63 \\
2.38\end{array}$ & $\begin{array}{r}66.5 \\
79.8 \\
122.7 \\
66.4 \\
40.06\end{array}$ & $\begin{array}{r}10.79 \\
7.81 \\
41.18 \\
39.02 \\
1.20\end{array}$ & $\begin{array}{l}240.5 \\
251.5 \\
269.2 \\
162.0 \\
133.5\end{array}$ & $\begin{array}{r}15.21 \\
10.96 \\
35.19 \\
37.08 \\
1.56\end{array}$ \\
\hline winter & $\begin{array}{r}\text { I } \\
\text { II } \\
\text { III } \\
\text { IV } \\
\text { V }\end{array}$ & $\begin{array}{r}6.87 \\
11.16 \\
40.06 \\
39.81 \\
0.32\end{array}$ & $\begin{array}{r}88.5 \\
125.5 \\
134.9 \\
59.3 \\
124.5\end{array}$ & $\begin{array}{r}6.20 \\
14.27 \\
55.07 \\
24.06 \\
0.41\end{array}$ & $\begin{array}{l}327.4 \\
468.3 \\
298.8 \\
150.7 \\
500.3\end{array}$ & $\begin{array}{r}8.78 \\
20.41 \\
46.75 \\
23.43 \\
0.63\end{array}$ \\
\hline Annual & $\begin{array}{r}\text { I } \\
\text { II } \\
\text { III } \\
\text { IV } \\
\text { V }\end{array}$ & $\begin{array}{r}12.70 \\
10.84 \\
33.52 \\
39.03 \\
1.89\end{array}$ & $\begin{array}{r}75.0 \\
88.7 \\
113.8 \\
61.7 \\
57.0\end{array}$ & $\begin{array}{r}11.55 \\
11.66 \\
46.27 \\
29.21 \\
1.31\end{array}$ & $\begin{array}{l}262.2 \\
320.4 \\
248.4 \\
149.4 \\
196.3\end{array}$ & $\begin{array}{r}15.61 \\
16.28 \\
39.03 \\
27.34 \\
1.74\end{array}$ \\
\hline
\end{tabular}


TABLE lb. Region II, representative station: New York, NY (JFK)

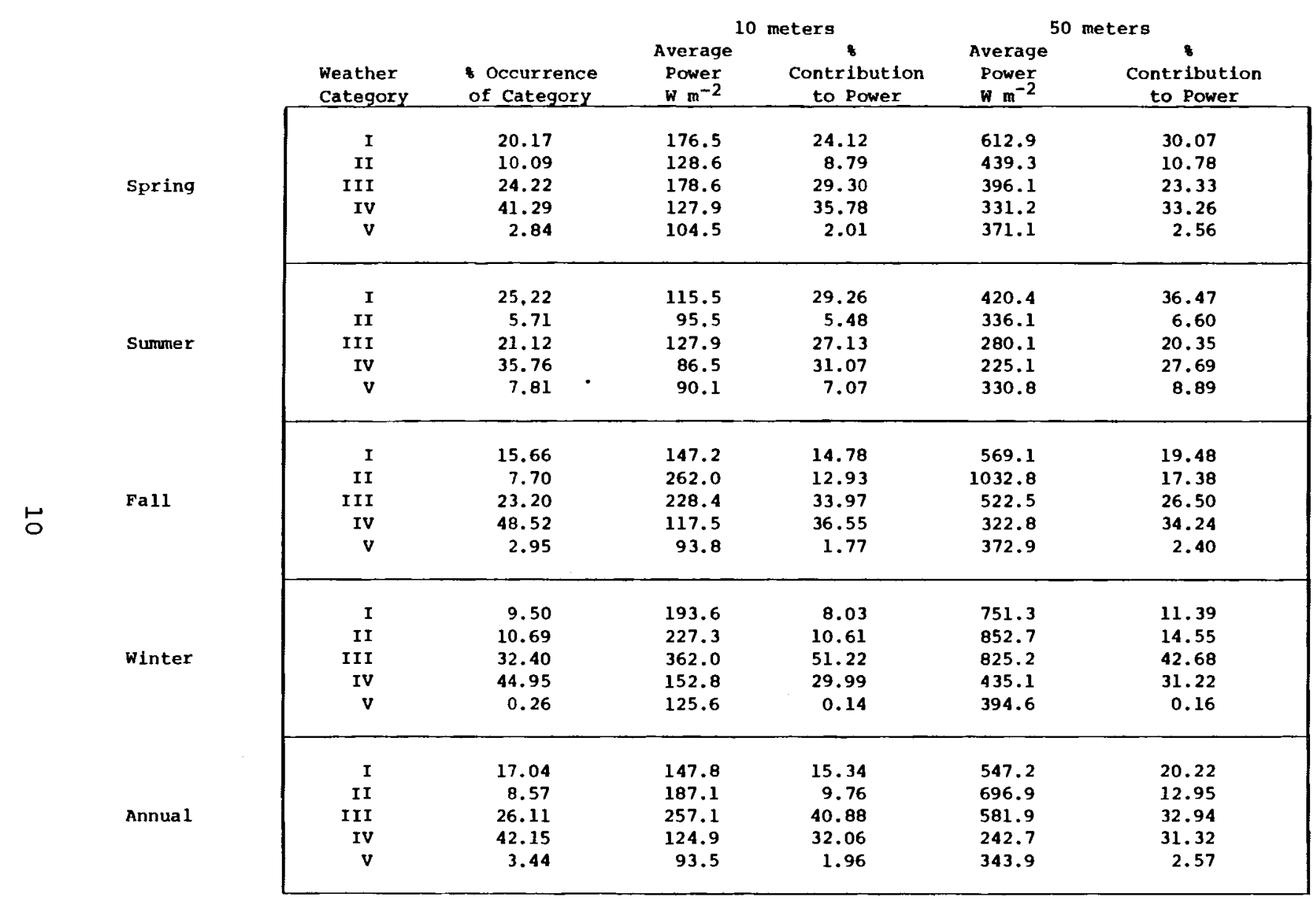


TABLE 1C. Region III, representative station: Hampton, VA

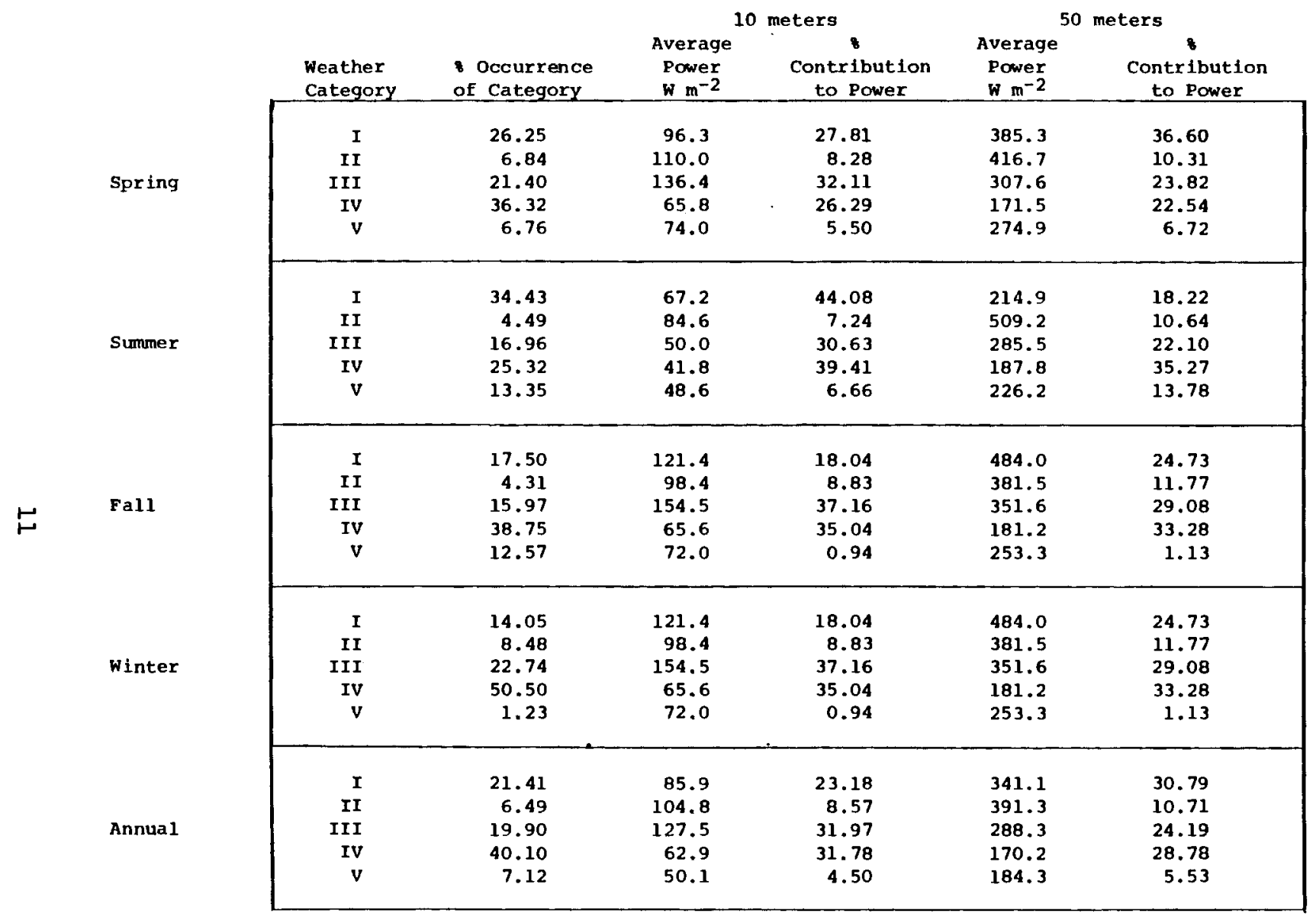


TABLE 1d. Region IV, representative station: Charleston, SC

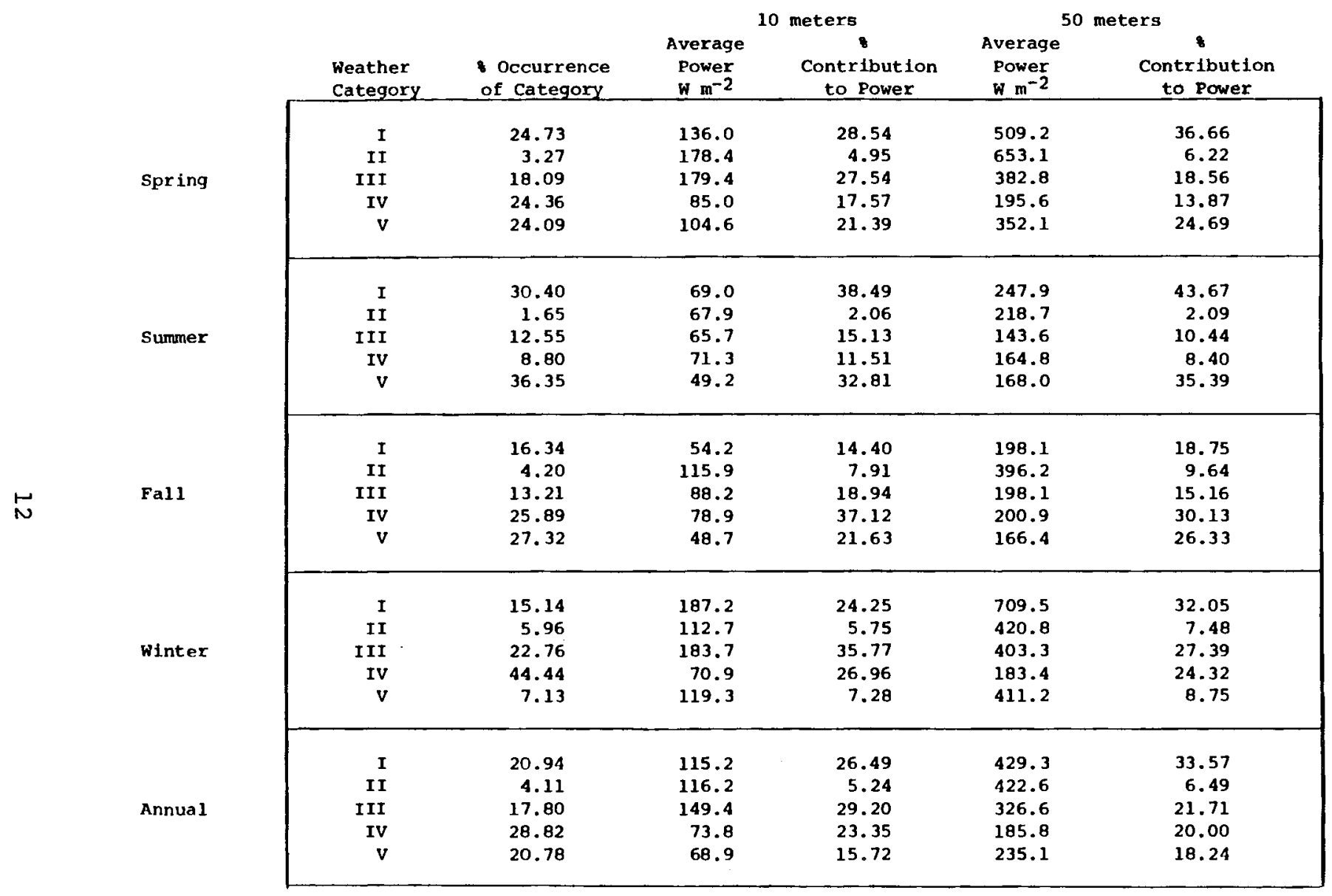


TABLE le. Region V, representative station: Mobile, AL

\begin{tabular}{|c|c|c|c|c|c|c|}
\hline & & & & meters & & ters \\
\hline & $\begin{array}{l}\text { Weather } \\
\text { Category }\end{array}$ & $\begin{array}{l}8 \text { Occurrence } \\
\text { of Category }\end{array}$ & $\begin{array}{l}\text { Average } \\
\text { Power } \\
\omega \mathrm{m}^{-2}\end{array}$ & $\begin{array}{c}\text { Contribution } \\
\text { to Power }\end{array}$ & $\begin{array}{l}\text { Average } \\
\text { Power } \\
w^{-2}\end{array}$ & $\begin{array}{c}\text { Contribution } \\
\text { to Power }\end{array}$ \\
\hline & I & 14.40 & 109.8 & 19.93 & 432.4 & 24.50 \\
\hline & II & 2.50 & 111.3 & 3.51 & 477.7 & 4.70 \\
\hline Spring & III & 11.98 & 117.9 & 17.80 & 259.5 & 12.23 \\
\hline & IV & 24.57 & 72.9 & 22.57 & 188.0 & 18.17 \\
\hline & $v$ & 40.34 & 71.2 & 36.20 & 254.5 & 40.40 \\
\hline & I & 15.19 & 32.5 & 16.98 & 123.8 & 19.36 \\
\hline & II & 0.73 & 43.1 & 1.08 & 146.9 & 1.10 \\
\hline Surmer & III & 7.09 & 45.0 & 10.98 & 99.3 & 7.25 \\
\hline & IV & 3.30 & 40.8 & 4.63 & 104.6 & 3.55 \\
\hline & $v$ & 61.99 & 31.1 & 66.33 & 107.7 & 68.73 \\
\hline & I & 9.69 & 42.4 & 9.27 & 176.8 & 12.63 \\
\hline & II & 3.52 & 81.1 & 6.44 & 284.4 & 7.38 \\
\hline Fall & III & 11.80 & 93.2 & 24.82 & 225.1 & 19.58 \\
\hline & IV & 25.47 & 61.8 & 35.53 & 161.0 & 30.23 \\
\hline & $\mathrm{v}$ & 38.28 & 27.7 & 23.93 & 106.9 & 30.17 \\
\hline & $\mathbf{I}$ & 10.62 & 138.2 & 14.19 & 530.0 & 17.84 \\
\hline & II & 7.02 & 131.3 & 8.91 & 535.6 & 11.91 \\
\hline Winter & III & 13.73 & 161.5 & 21.44 & 375.4 & 16.33 \\
\hline & IV & 54.65 & 82.0 & 43.32 & 225.6 & 39.07 \\
\hline & $v$ & 11.09 & 113.3 & 12.15 & 422.5 & 14.85 \\
\hline & I & 12.35 & 83.1 & 15.03 & 322.4 & 18.71 \\
\hline & II & 3.92 & 116.7 & 6.70 & 469.8 & 8.66 \\
\hline Annua 1 & III & 11.24 & 120.8 & 19.88 & 279.1 & 14.75 \\
\hline & IV & 30.28 & 76.6 & 33.96 & 207.6 & 29.55 \\
\hline & v & 34.85 & 47.9 & 24.44 & 173.0 & 28.34 \\
\hline
\end{tabular}


TABLE 1f. Region VI, representative station: Miami, FL

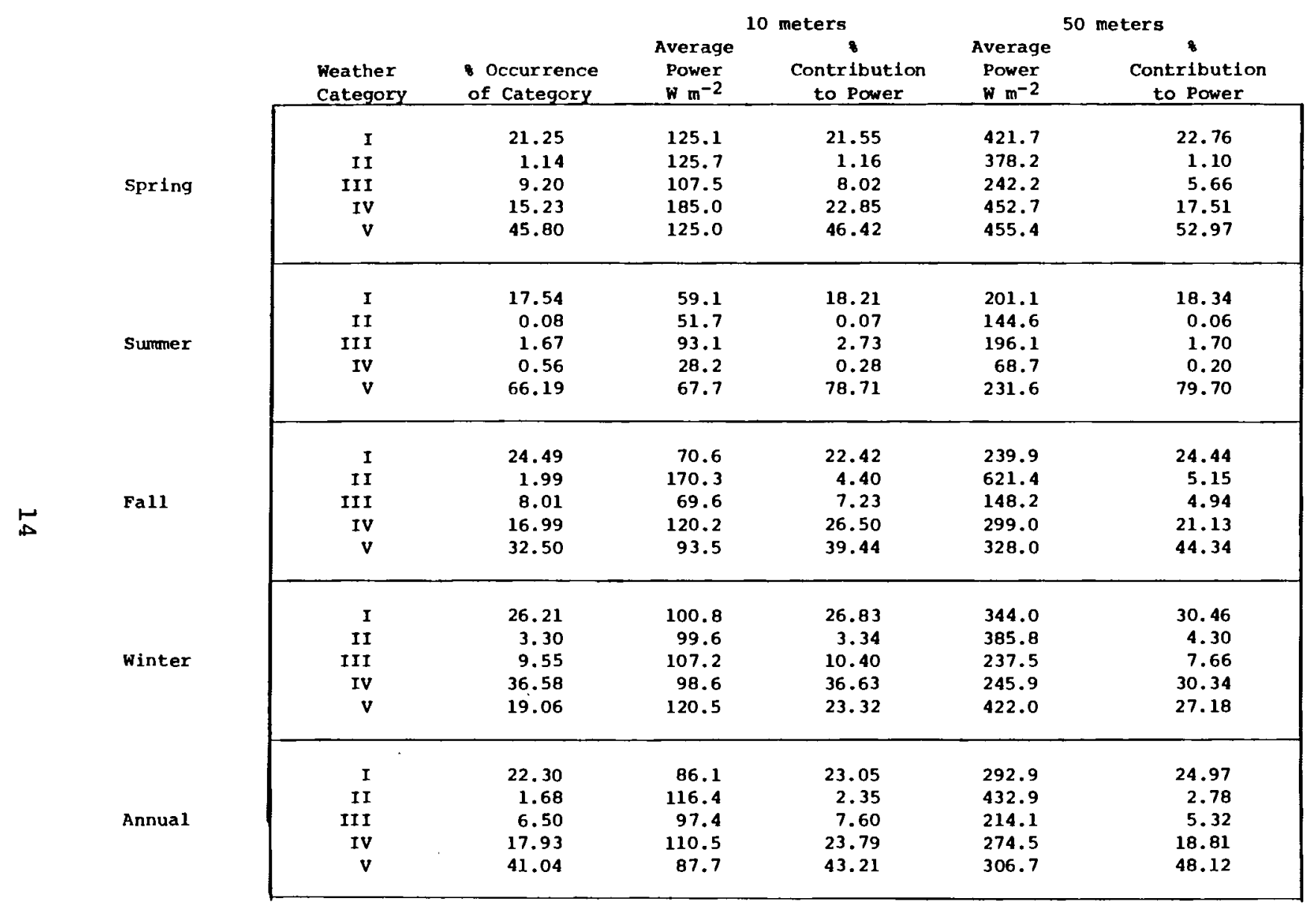


TABLE 1g. Region VII, representative station: Brownsville, TX

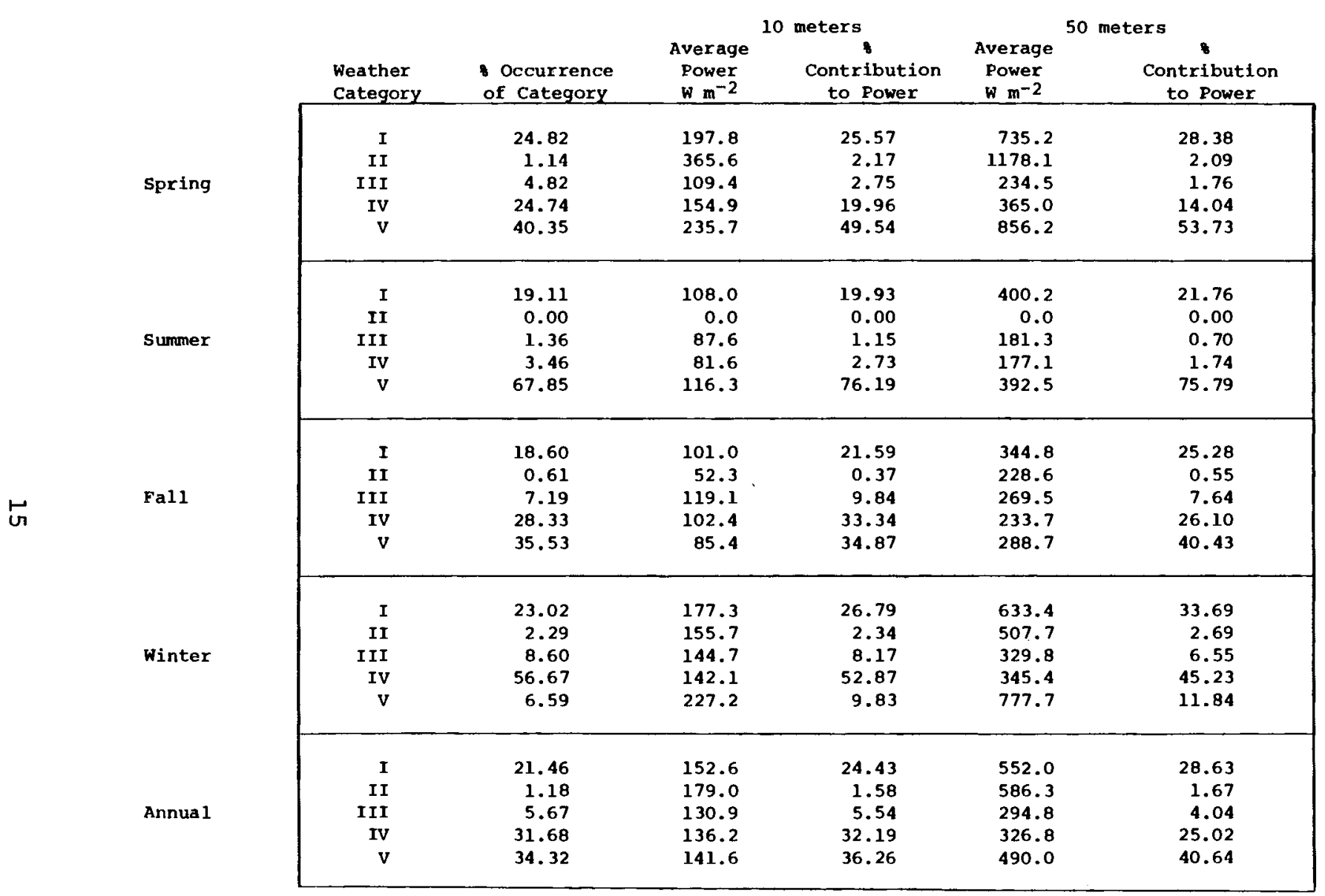


TABLE 2. Mean annual power density $\left(\mathrm{w} \mathrm{m}^{-2}\right)$ for the layer $10-100 \mathrm{~m}$ shown for each $100 \mathrm{~km}^{2}$ (10 km north-south $\times 10 \mathrm{~km}$ east-west) for each grid area corresponding to
a) Chesapeake Bay, Figure $3 a$
b) Apalachee Bay, Figure 3b
c) South Texas Coast, Figure 3c 


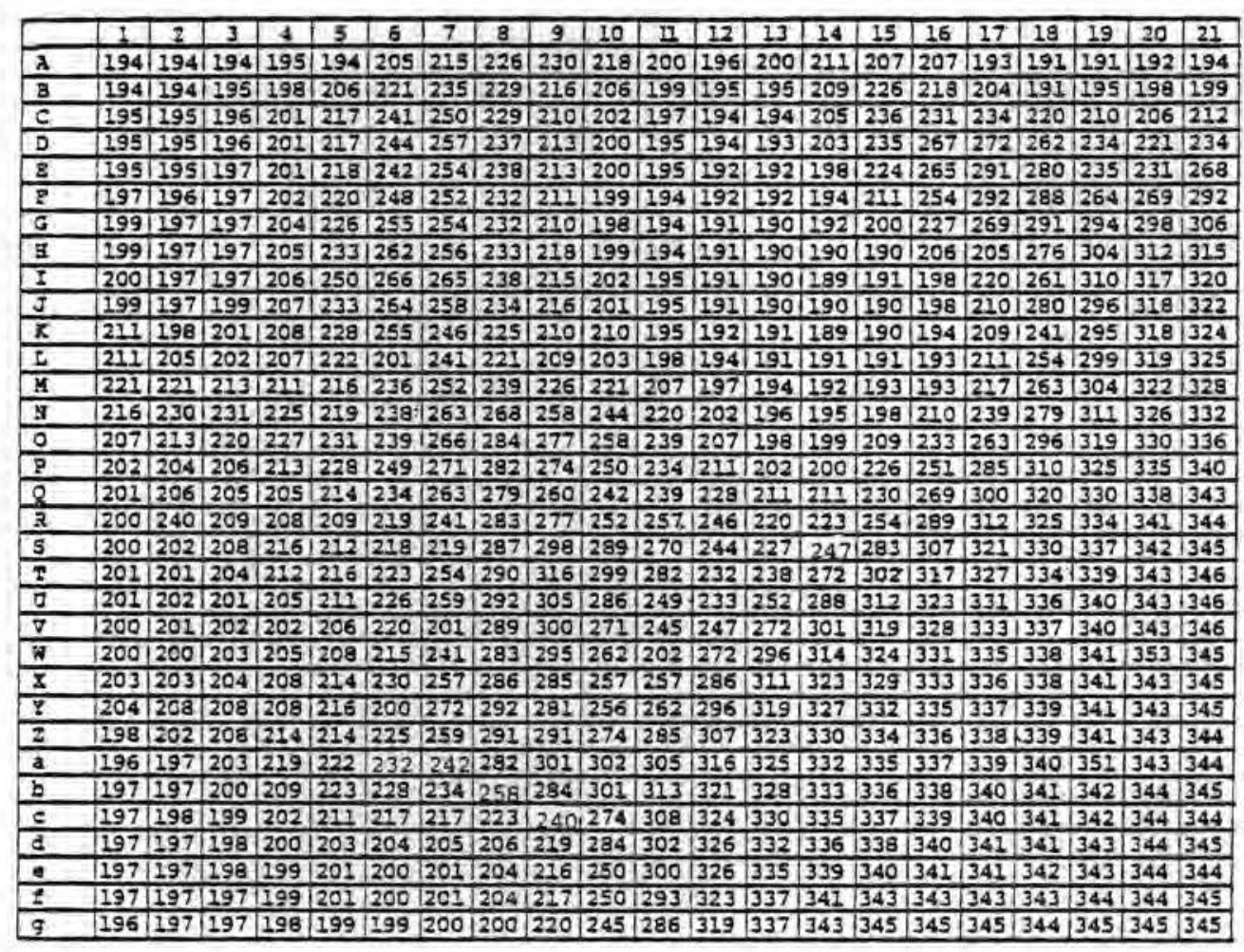

TABLE 2a. Chesapeake Bay 


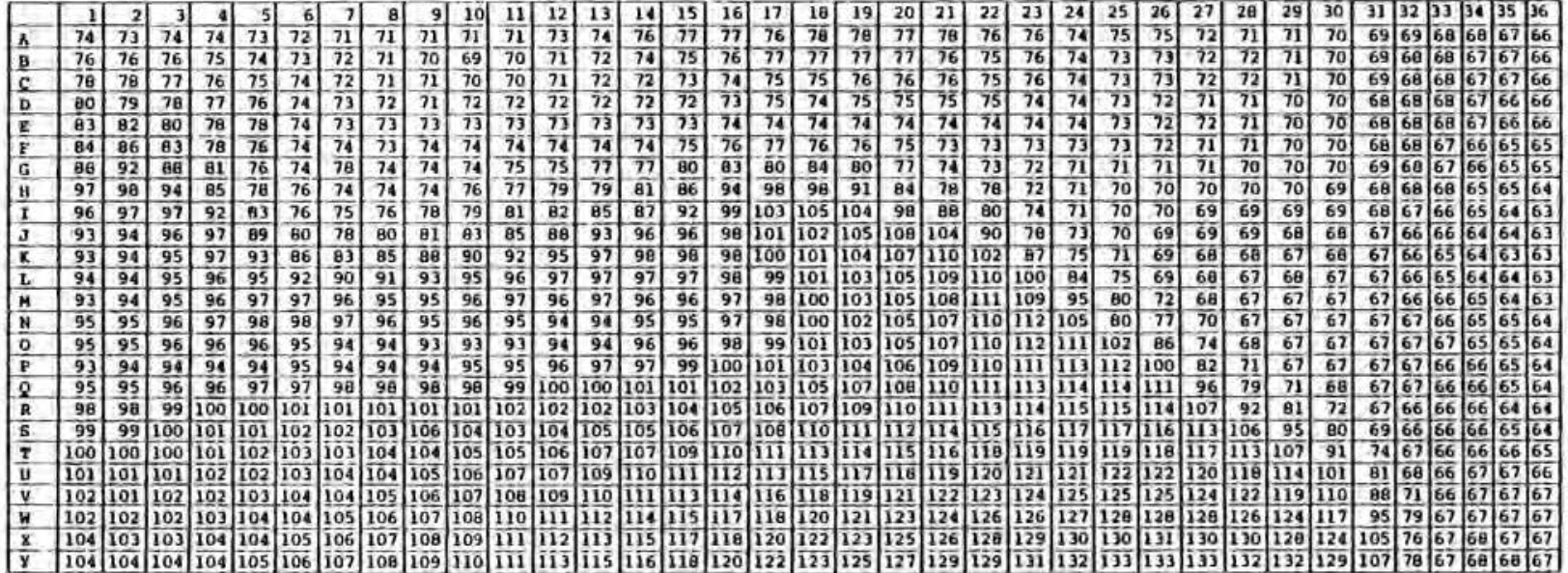

TABLE 2b. Apalachee Bay 


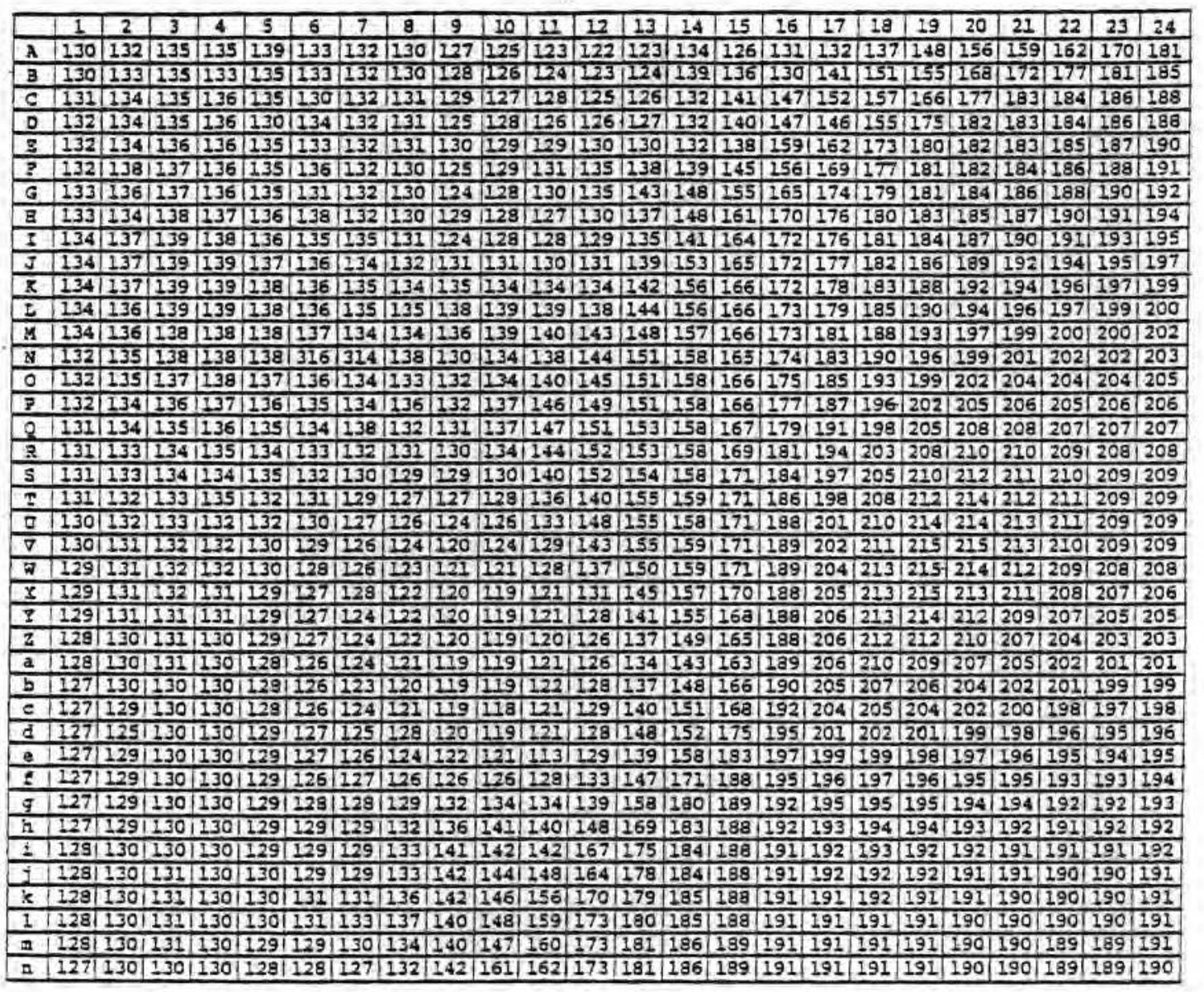

TABLE 2c. South Texas coast 
TABLE 3. Coastal Statlong used In the verification of 100 a Layer-Mean Annual Averaya Fower Benglly.

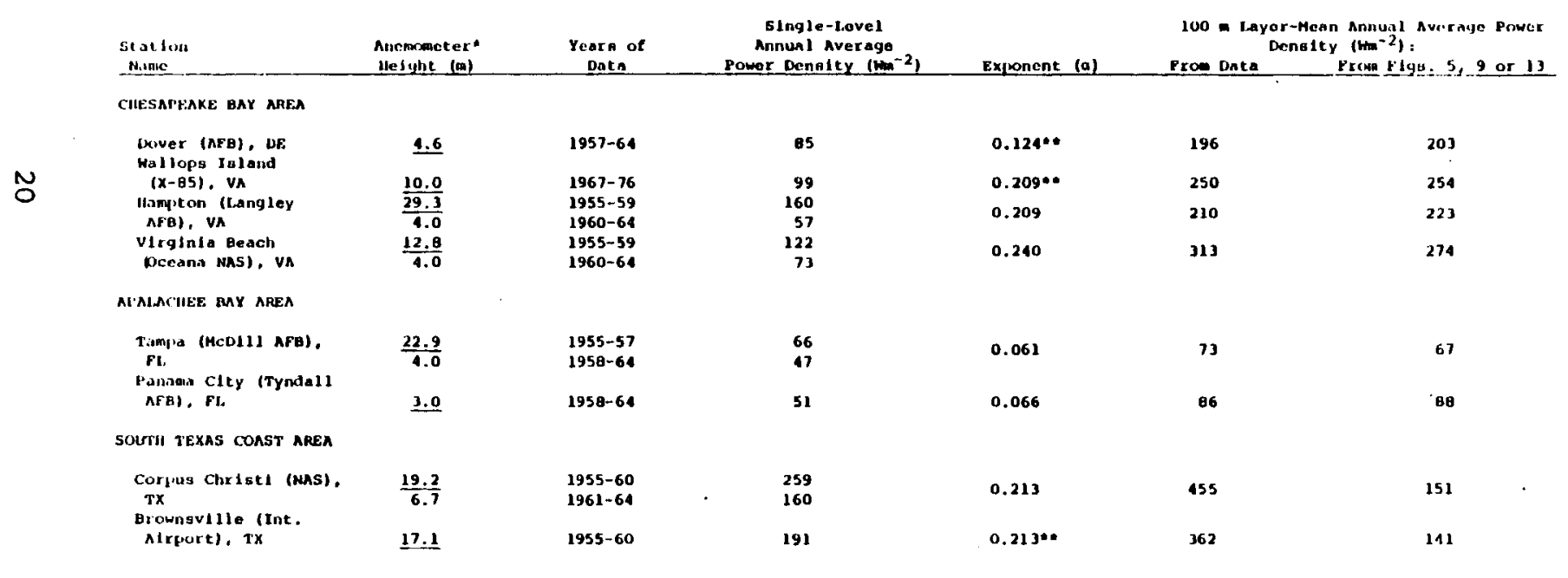

AUniterlined helghts uned as basis for comput Ing layer-mean values.

"Exponent not deteralnabla for this atations value of nearest atation used. (In the case of Dover, re, Atlantic City, Nu was used.) 
FIGURE 1. Regional demarcations of coastal zone and seven representative stations.

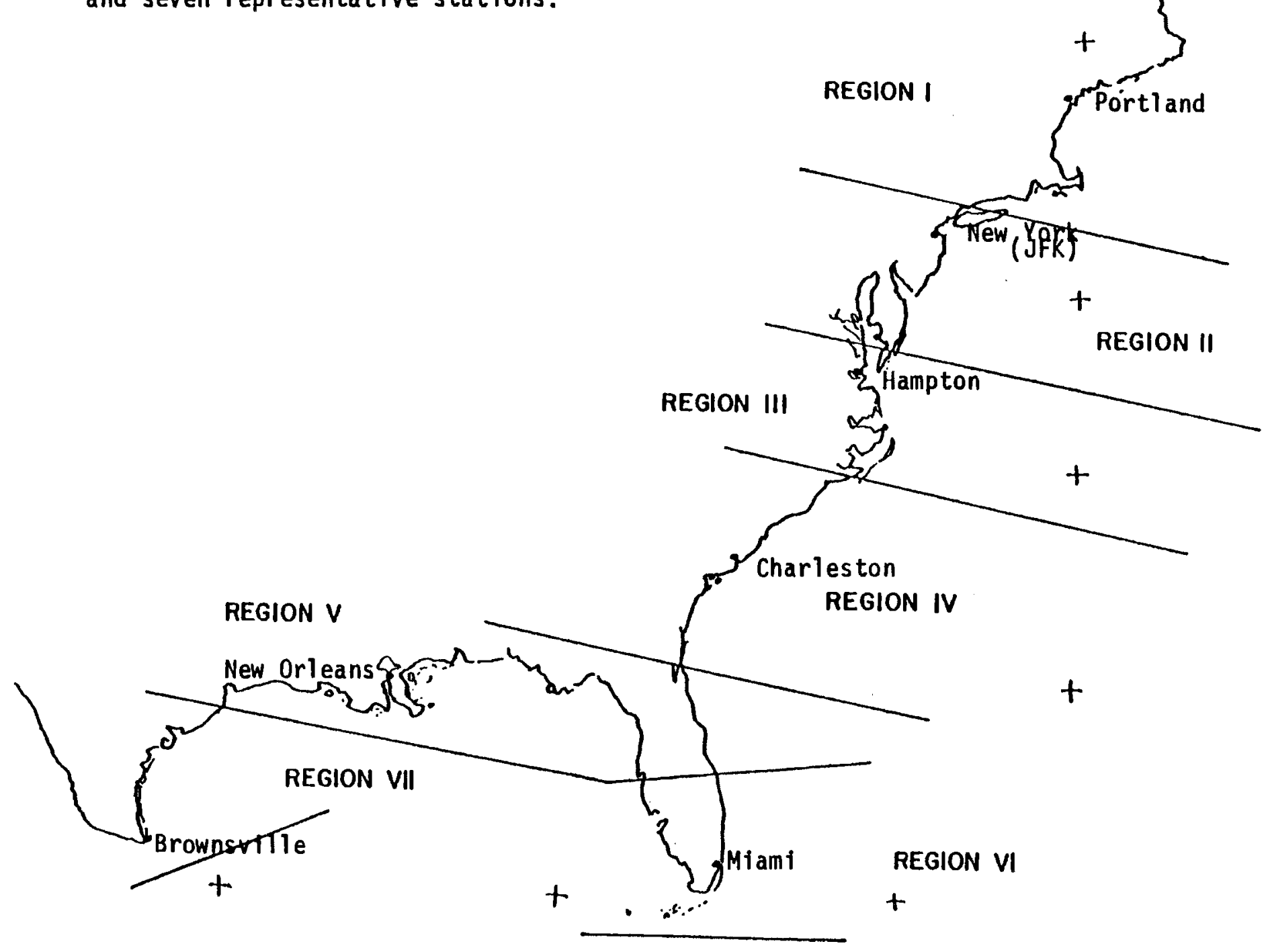


FIGURE 2. Location of test regions.

\section{CB - Chesapeake Bay}

$A B$ - Apalachee Bay

ST - South Texas coast

Annual average wind speed $\left(\mathrm{m} \mathrm{s}^{-1}\right)$ normalized to

$10 \mathrm{~m}$ above the ground for 36 coastal locations

is also shown.
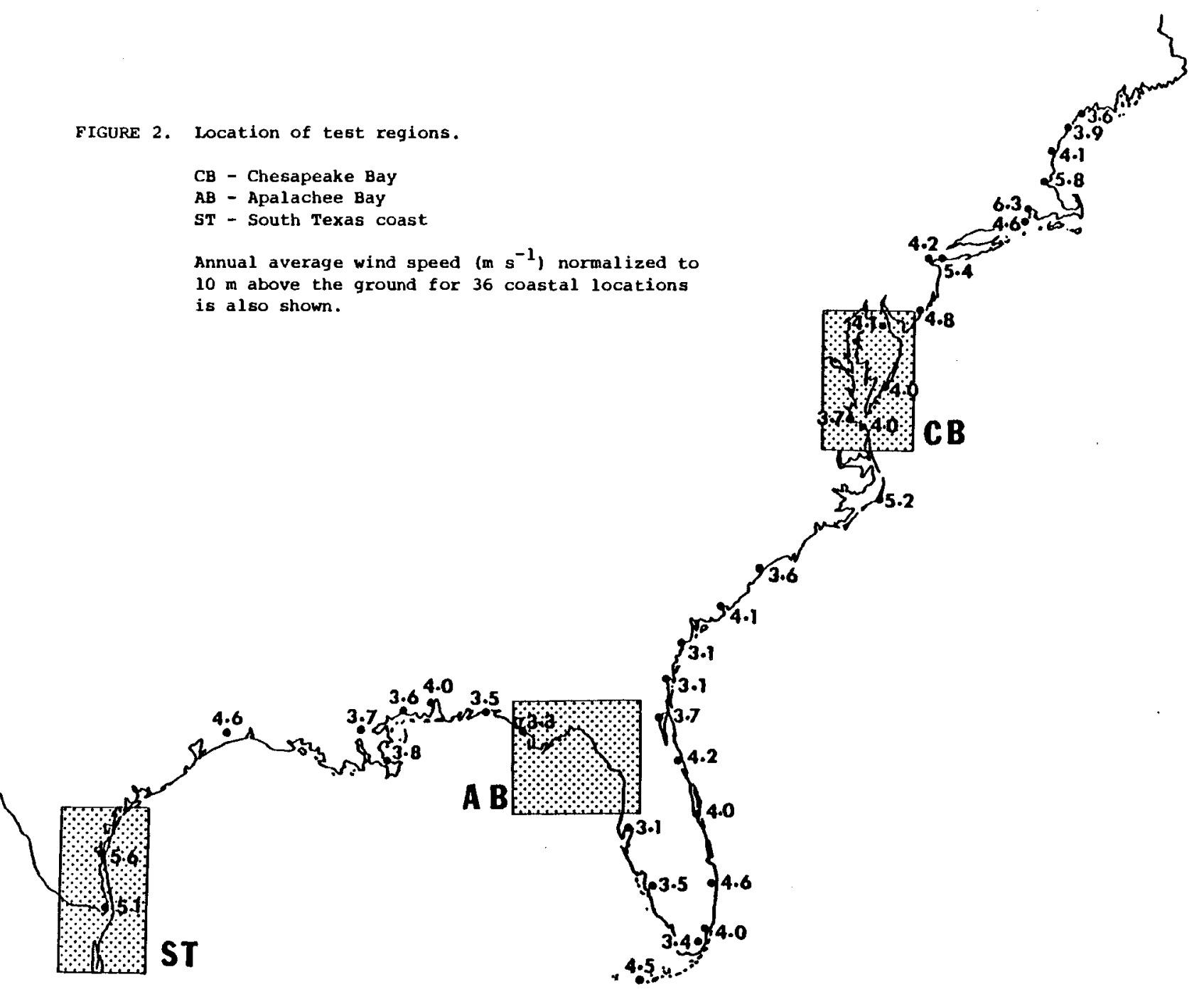
FIGURE 3. Mean annual power density $\left(\mathrm{W} \mathrm{m}^{-2}\right)$ for the layer $10-100 \mathrm{~m}$ for each of the test regions shown in Figure 2. Centers of relative maximum $(\mathrm{X})$ and minimum $(\mathrm{N})$ are indicated along with solid isolines drawn at $50 \mathrm{~W} \mathrm{~m}^{-2}$ intervals. Values of mean annual power density for each $10 \times 10 \mathrm{~km}$ grid area can be obtained by referring grid location to Table 2 .

a) Chesapeake Bay: Intersections of $75^{\circ}, 76^{\circ}$ and $77^{\circ} \mathrm{W}$ with $37^{\circ}, 38^{\circ}$ and $39^{\circ} \mathrm{N}$ are marked. Table $2(a)$ gives the $10 \times 10 \mathrm{~km}$ grid of mean annual power density values.

b) Apalachee Bay: Intersections of $83^{\circ}, 84^{\circ}$ and $85^{\circ} \mathrm{W}$ with $29^{\circ}$ and $30^{\circ} \mathrm{N}$ are marked. Table $2(\mathrm{~b})$ gives the $10 \times 10 \mathrm{~km}$ grid of mean annual power density values.

c) South Texas Coast: Intersections of $97^{\circ}$ and $98^{\circ} \mathrm{W}$ with $25^{\circ}, 26^{\circ}, 27^{\circ}$ and $28^{\circ} \mathrm{N}$ are marked. Table $2(\mathrm{c})$ gives the $10 \times 10 \mathrm{~km}$ grid of mean annual power density values. 


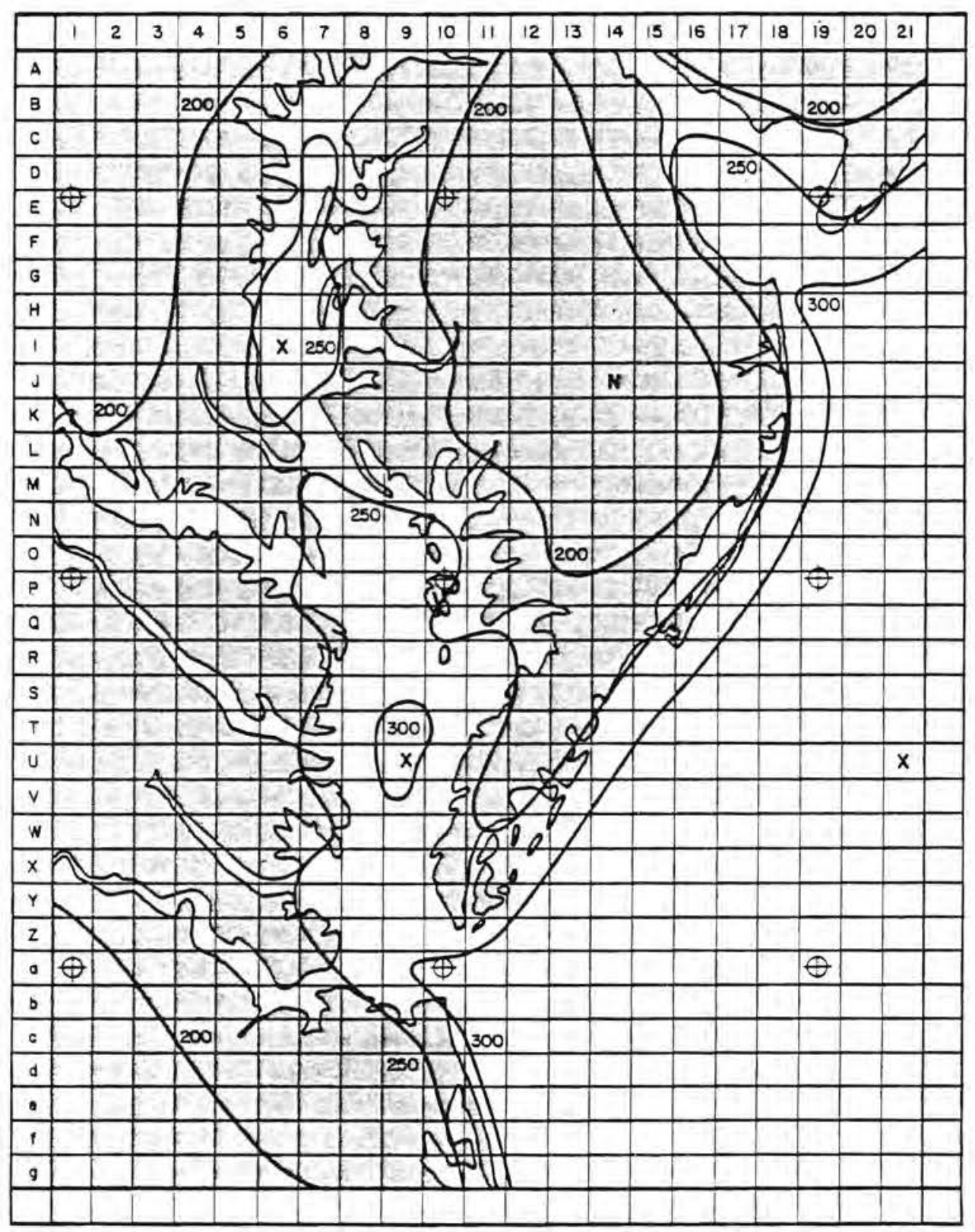

FIGURE 3a. Chesapeake Bay 
FIGURE 3b, Apalachee Bay

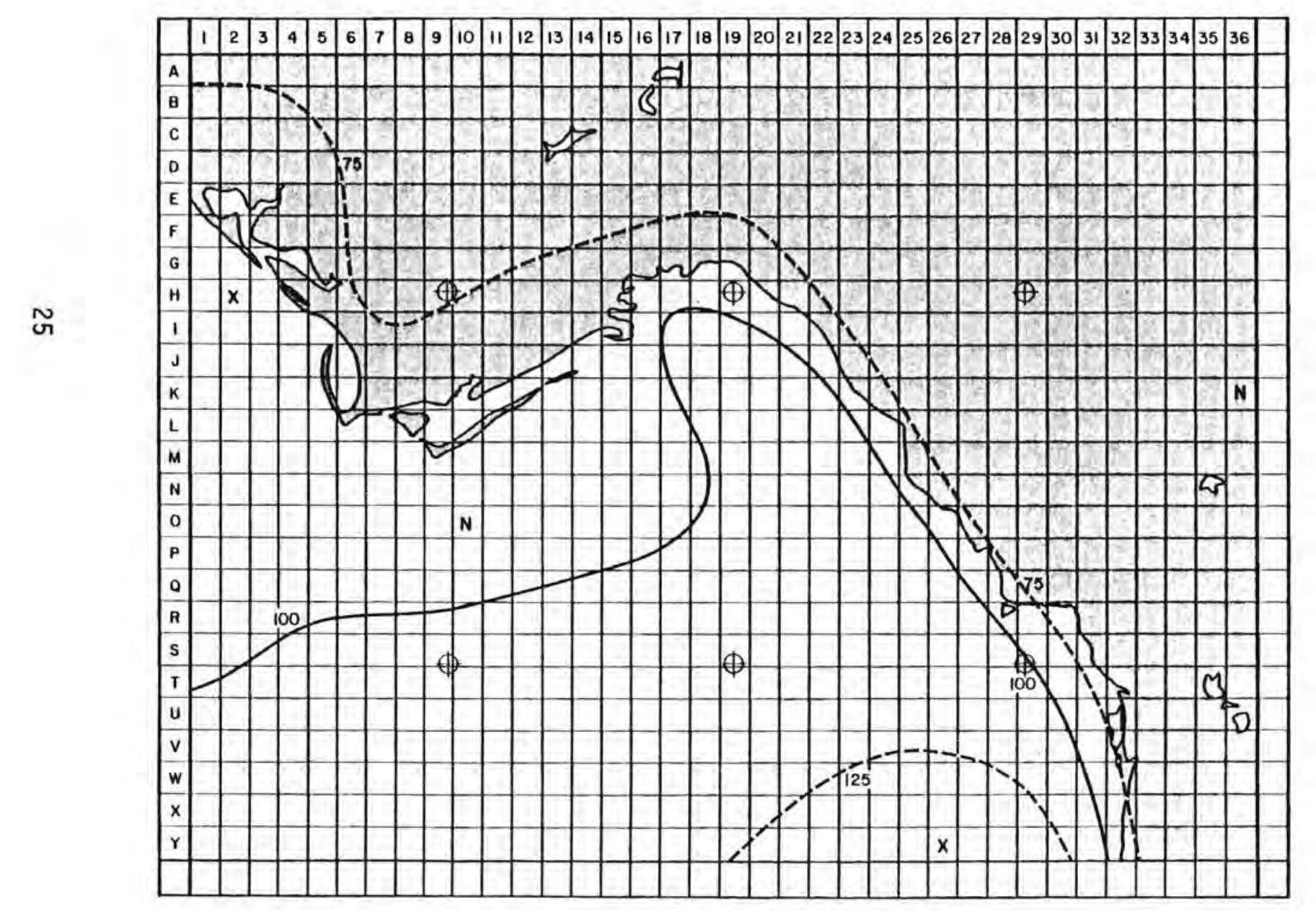




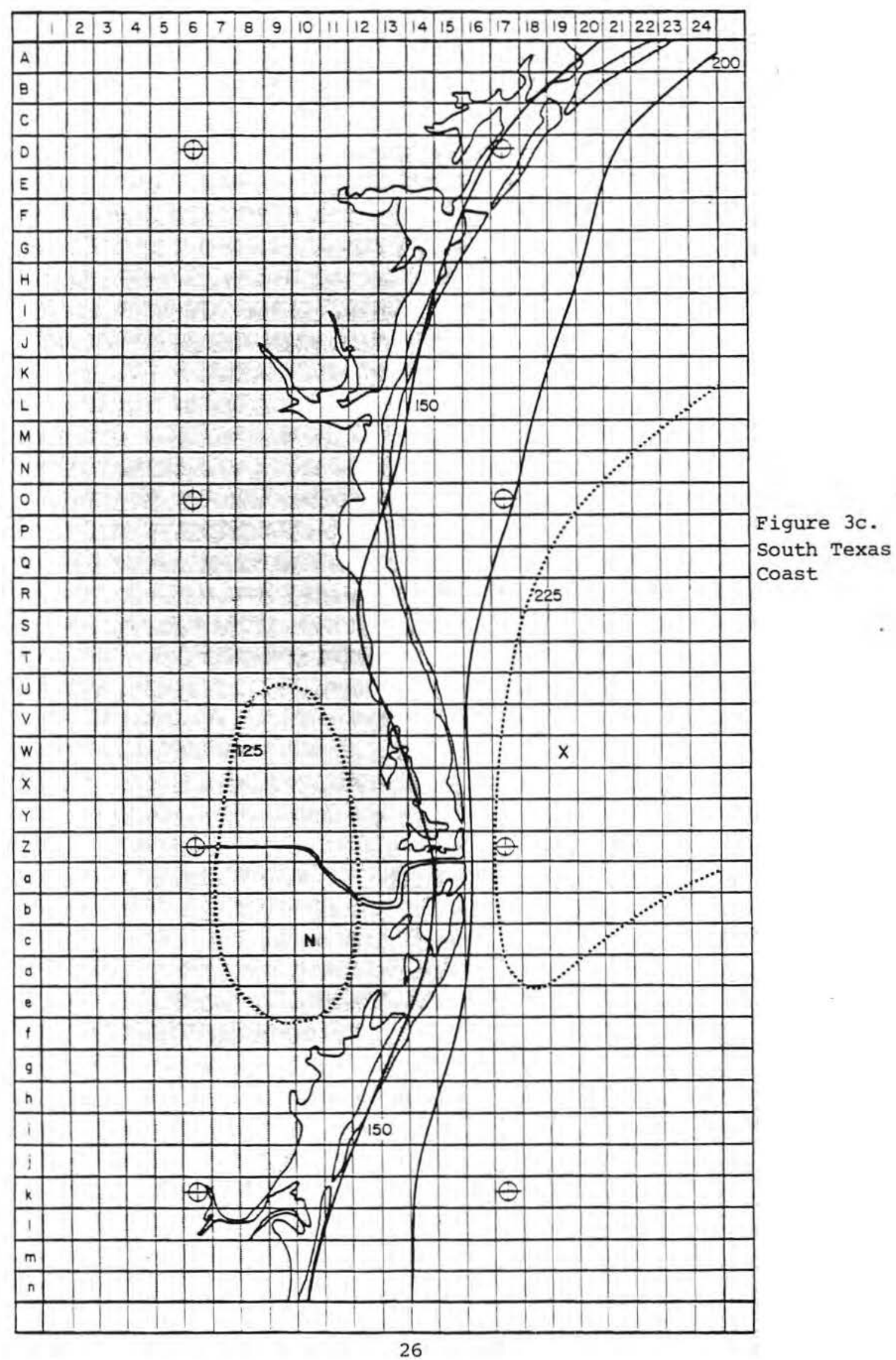


APPENDIX 1

THE SKILL OF THE MODEL 
Measurements of wind speed and direction were made over a $30 \times 120$ $\mathrm{km}$ rectangle lying across the Delmarva Peninsula in late January and early February, 1980. Two days representing weather category III (see Table 1 and Appendix 2) were selected to test the ability of the model to reproduce the observed winds.

The mesoscale numerical model of the atmosphere is used to produce the "predicted" winds. The initialization of the model was accomplished using pre-dawn meteorological conditions. The integration of the model encompassed all daylight hours of each day.

Approximately 200 two-minute average (based on 120 observed values) wind speeds were "observed" on each day. These are compared to the spatially and temporally coincident values produced by the model. (Only wind-speeds are compared. Wind directions are not considered because no model produced direction differed from its coincident measured value by more than $15^{\circ}$. For wind power purposes this departure is not regarded as important.) On 30 January and 3 February a total of 409 wind speed measurements were made. Of the model predictions 308 were within the measurement error. Therefore, based upon the criterion that error in excess of that attributable to measurement is due to poor predictive ability, the model has a 758 skill in reproducing observed wind speeds.

The skill of any numerical simulation is not solely due to the integrations performed. The representativeness of the initialization procedure has a comparable impact upon the resulting predictions. The separation of the two skills is difficult without the expenditure of considerable computer resources on sensitivity tests. Nevertheless, it is approximately true to ascribe the spatial and temporal variations to the model's operations and the mean values to the initialization. The computation of the coefficient of linear correlation between predicted and observed wind speeds emphasizes the variations. On 30 January the coefficient was 0.79 , on the 3rd of February 0.75 . The correlation analysis thus suggests a 778 skill for the model itself.

An analysis of the departures between prediction and observed wind speeds, when the bias due to differing means is removed, also serves to evaluate the model's skill. This analysis gives a value of 818 skill for the 30 th and $76 \%$ for the $3 \mathrm{rd}$, i.e. $78 \%$ overall. It is therefore concluded that the model's ability to reproduce wind speeds in the vicinity of a coastline is most likely $77 \%$.

A skill rating of $77 \%$ implies a percent error in predictions of 23\%. Since wind power varies on the cube of wind speed, it is anticipated that the percent error in wind power predictions will be three times that in wind speed, i.e. approximately 70\%. In Figures 1.A and 1.B the cube of the observed wind speeds is plotted against predicted wind speed. Various percent error isolines are plotted. 
The set $(+)$ of isolines which contains $68 \%$ of all points, i.e. the $t$ 1 standar $\bar{d}$ deviation limit, is 338 . The set which contains $95 \%$, the +2 standard deviation limit, is 708 . Therefore, if a one-in-three chance of being wrong is acceptable, the percent error in wind power predictions by the model is 33\%. If only a one-in-twenty chance can be tolerated, then the percent error is $70 \%$.

Error analysis of the observations can be carried out in terms of the measurement platform used. Known sources of error can be explicitly included (e.g. for the aircraft drift in the inertial navigation system). Unknown sources of error cannot be accounted for. Most routine (operational) field measurements of wind speed probably do not reproduce the theoretical true wind by more than 908 and many as low as or lower than 758. We conclude that for the conditions measured, the model has a skill comparable to that of routine observations. 


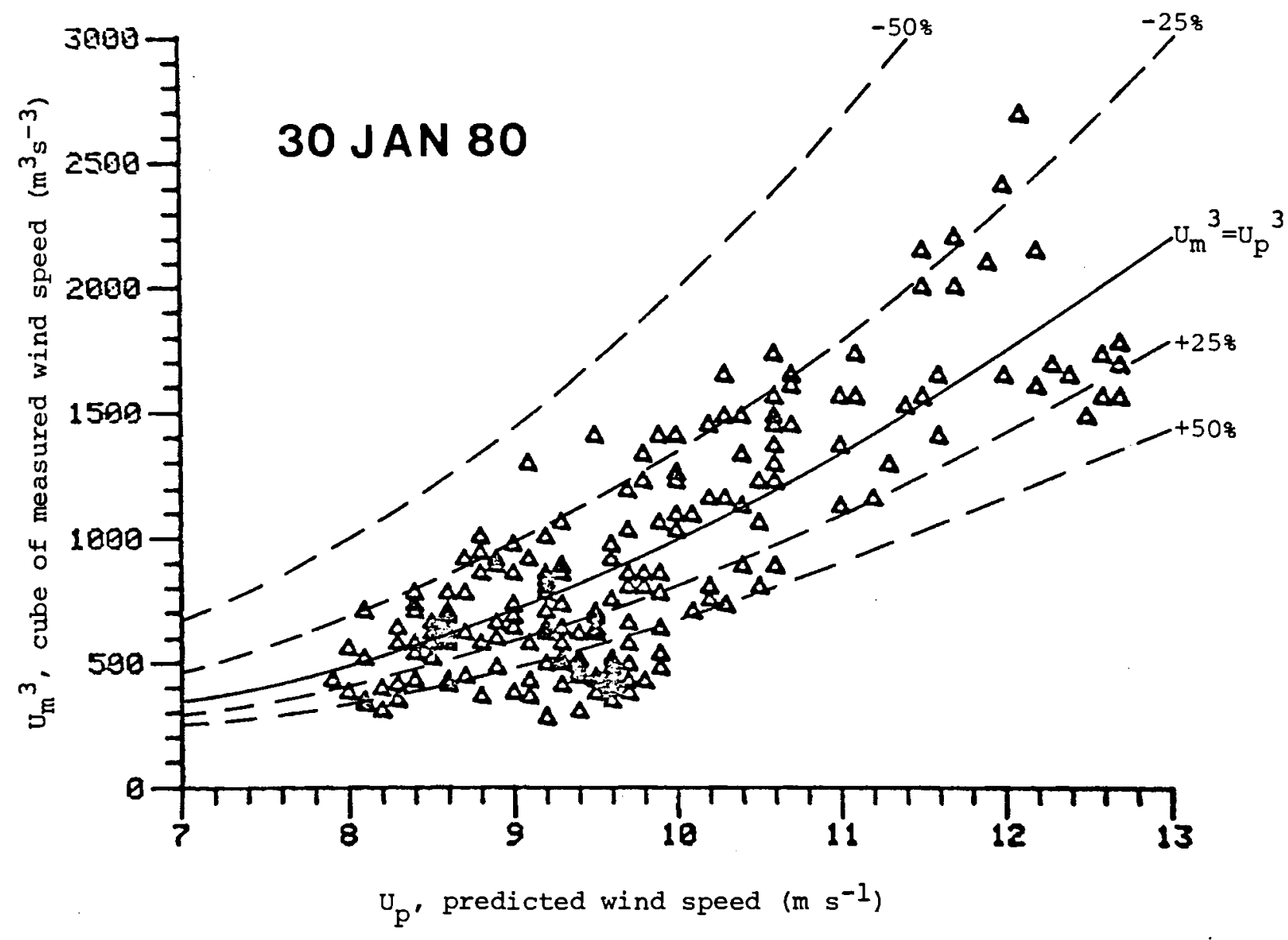

FIGURE 1.A. Scatter diagram of the cube of measured wind speed, $U_{m}{ }^{3}$, versus predicted wind speed, $U_{p}$, for 30 January 1980. Isolines of percent error in predicted wind power, $\left(U_{p}{ }^{3}-\right.$ $\left.U_{m}{ }^{3}\right) / U_{m}{ }^{3}=l \ell$, where $l \ell=-50,-25,+0,+25$ and $+50 \%$, are plotted. (Actually, $\mathrm{U}^{3}$ is specific kinetic energy flux and not wind power. Since the percent error in atmospheric density contributes little to the percent error in power, the $l \ell$ values are essentially the percent errors in power.) Over-predictions are below, underpredictions above the +0 or error, the solid line. 


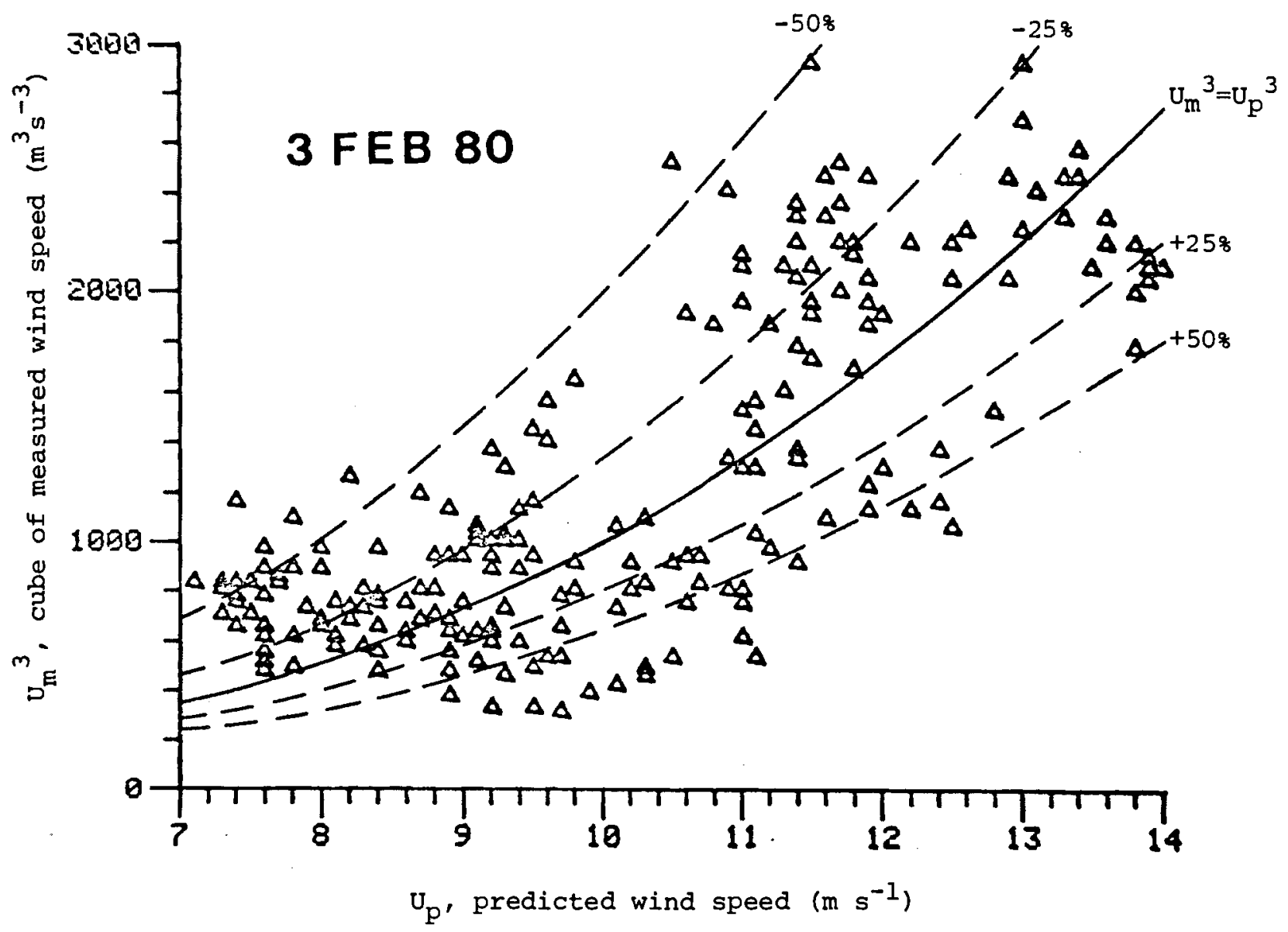

FIGURE 1.B. Scatter diagram of the cube of measured wind speed, $\mathrm{U}_{\mathrm{m}}{ }^{3}$, versus predicted wind speed, $U_{p}$, for 3 February 1980. Isolines of percent error in predicted wind power, $\left(\mathrm{U}_{\mathrm{p}}{ }^{3}-\right.$ $\left.\mathrm{U}_{\mathrm{m}}{ }^{3}\right) / \mathrm{U}_{\mathrm{m}}{ }^{3}=\ell \ell$, where $\ell \ell=-50,-25,+0,+25$ and $+50 \%$, are plotted. (Actually, $\mathrm{U}^{3}$ is specific kinetic energy flux and not wind power. Since the percent error in atmospheric density contributes little to the percent error in power, the $\ell \ell$ values are essentially the percent errors in power.) Over-predictions are below, underpredictions above the \pm 0 s error, the solid line. 
APPENDIX 2

DEFINITION OF WEATHER CATEGORIES 
Figure 2.A shows the frontal cyclone and surface low and high pressure systems with the associated regions labelled $I-V$ for each of the five weather categories.

Each category is defined below together with a description of the physical state of the atmosphere represented by that category:

Category I: in the warm sector, i.e., ahead of the cold front and/or behind the warm front, with generally a straight isobaric pattern.

This region is generally characterized by an overlying upper-level ridge. The subsidence associated with this ridge will favor a relatively stable thermal stratification. The low-level pressure gradient is usually weak or moderate. The air mass type is maritime tropical (mT).

Category II: ahead of the warm region in the region of cyclonic curvature of the isobars.

This region is generally characterized by warmer air overriding colder air near the ground, thereby favoring a comparatively stable thermal stratification. The cyclonic curvature of the isobars, with its associated low-level frictional convergence, will compensate somewhat for the stabilizing influence of the overlying warm air, but the vertical thermal gradient is expected to be dominant in general. The low-level pressure gradient is usually moderate to strong. The air mass is maritime polar, continental polar or continental arctic with maritime tropical above $\frac{\mathrm{mT}}{\mathrm{mP}}, \frac{\mathrm{mT}}{\mathrm{cP}}, \frac{\mathrm{mT}}{\mathrm{cA}}$.

Category III: behind the cold front in the region of cyclonic curvature of the isobars.

This region is generally characterized by an upper level trough, which, with its comparatively cold temperatures, will enhance mixing and thereby favor less stable stratification. The cyclonic curvature of the isobars will cause low-level frictional convergence and, therefore, upward motion, which will further aid the mixing. The low-level pressure gradient is usually moderate or strong. The air mass is continental polar or arctic (cP, CA). 
Category IV: under a continental polar or arctic high with anticyclonic curvature to the surface isobars.

This region is generally characterized by an upper level trough, which will enhance vertical mixing, while the low level isobaric pattern is oriented so as to somewhat reduce this mixing through boundary layer divergence with its resultant subsidence. The low-level pressure gradient is usually weak or moderate. The air mass is continental polar or arctic ( $\mathrm{CP}, \mathrm{CA})$.

Category V: in the vicinity of the subtropical ridge with anticyclonic curvature to the surface isobars.

This region is generally characterized by an overlying upper-level ridge and boundary layer frictional divergence. Both effects will act to promote a relatively stable thermal stratification. The low-level pressure gradient is usually weak or moderate. The air mass is maritime tropical (mT).

Categories I through IV are associated with the polar and arctic fronts. Category $\mathrm{V}$ is characteristic of the broad region of high pressure which circles the globe equatorward of the polar front. The number of times a site is north of the polar front (in categories II through IV) and south of the front (in categories $I$ and $V$ ) is used to estimate the Winter, spring, summer and Fall seasons at those locations. 
FIGURE 2.A. The observed synopt 1c weather map over the United States for 9 January 1964, along with the typlng of particular weather feature characteristics. The numbers plotted on the Figure lllustrate the method of binning these features.

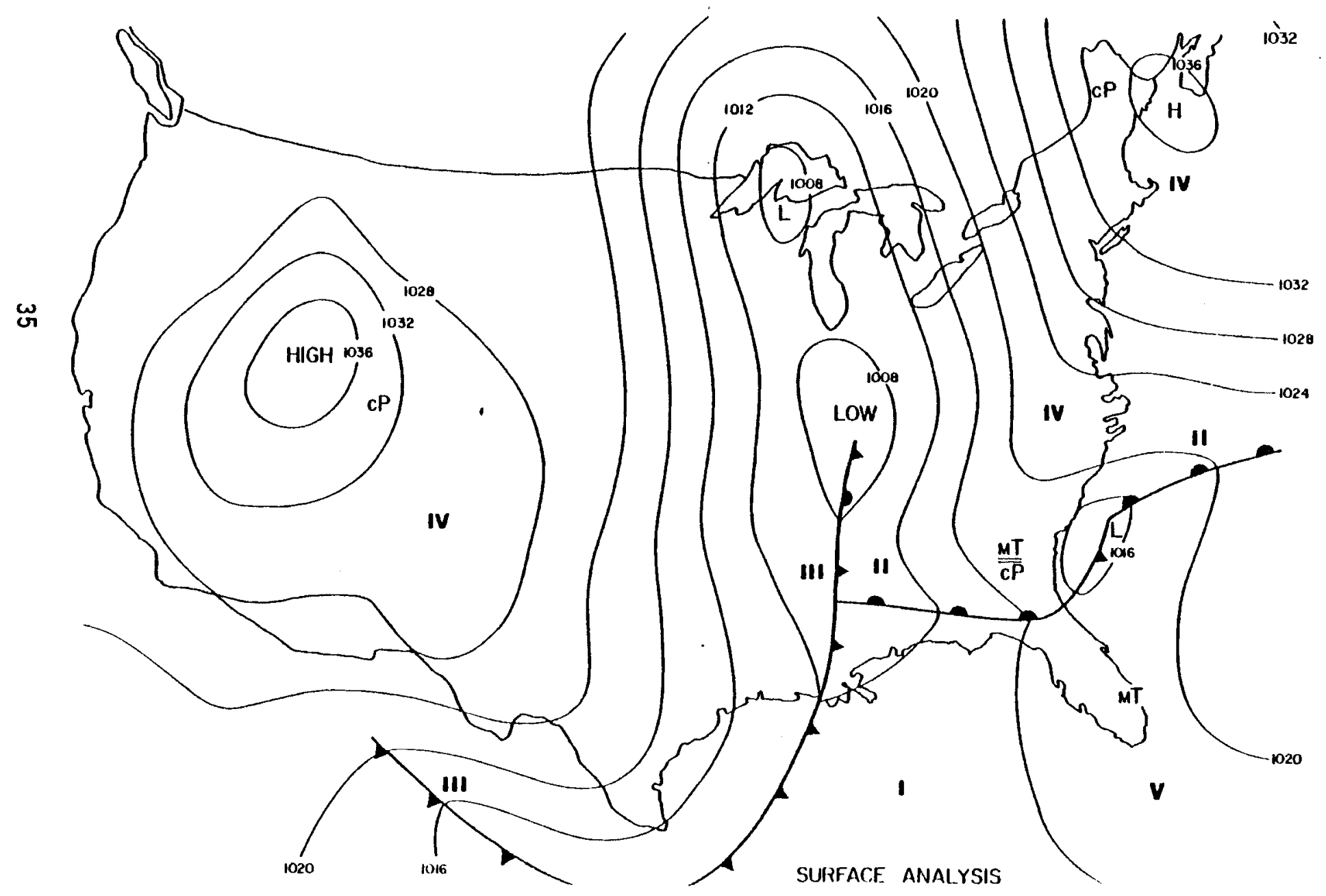


APPENDIX 3

MODEL PARAMETERS 
Required meteorological input is based upon:

1. A characterization of the dominant weather categories determined from Figure 1 and Table 1 . This may be done either by

a) determining the mean conditions for each of the chosen categories for the location of interest.

or

b) choosing a day typical of each of the chosen categories.

Choice of b) is simplest and is the method recommended.

2. Upper air structure:

Select the nearest rawinsonde station to the location of interest and for the days chosen as typical of each category determine the quantities listed in Table 3.A for either the 2-or 3-dimensional model.

3. Surface parameters:

For the location of interest determine from measurements available from such sources as the nearest National Weather Service (NWS)

station and from the NWS files the parameters listed in Table 3.A.

4. Other model specifications as listed in Table 3.A. 
TABLE 3.A. Required measurements and parameters to initialize the 2 or 3-D models. ( $\checkmark$ required, $x$ not required)

Element

\section{Upper Air}

1) geostrophic wind (meteor deg. and $\mathrm{m} / \mathrm{sec}$ )

$\omega$ 2) wind shear to $6 \mathrm{~km}$ (m $\mathrm{s}^{-1} \mathrm{~km}^{-1}$ )

a) u-component

b) v-component

3) initial depth of initial boundary layer (m)

4) free atmosphere lapse rate of potential temperature $\left(\mathrm{K} \mathrm{km}^{-1}\right)$

\section{Surface}

1) initial shelter height temperature $\left({ }^{\circ} \mathrm{C}\right)$
$2-D$

$3-D$

Source

NWS rawinsonde nearest location and time of start: geostrophic level chosen at height where a) wind shear approaches zero and b) where marked decrease in moisture begins.

NWS rawinsonde nearest location and time of start: a) take $6 \mathrm{~km}$ wind vector, b) subtract geostrophic wind vector, c) divide by $6 \mathrm{~km}$ minus geostrophic height

Same as height of geostrophic level

NWS rawinsonde determined 5 to $6 \mathrm{~km}$

Nearest NWS observation or NWS weather chart nearest time of start 
Table 3.A. (cont.)

Element

2) initial surface pressure (mb)

3) sea surface tempera- $\checkmark$ ture (C)

4) soil characteristics a) density $\left(\mathrm{g} \mathrm{cm}^{-3}\right)$

b) specific heat

c) diffusivity $\left(\mathrm{cm} \mathrm{s}^{-1}\right)$

d) wetness ( 8 )

5) surface albedo

6) surface roughness length $(\mathrm{cm})$

\section{Other Specifications}

1) mean latitude $\left({ }^{\circ} \mathrm{N}\right)$

2) horizontal grid interval $(\mathrm{km})$

3) length of section or size of domain $(\mathrm{km})$

4) number of vertical levels

$\checkmark$

2-D

3-D

$\sqrt{ }$

$\checkmark$

$\sqrt{ }$
$\checkmark$

$\sqrt{ }$

$\mathbf{x}$

$\sqrt{ }$

$\sqrt{ }$

$\sqrt{ }$

$$
\checkmark
$$

$\sqrt{ }$

2 to 10

50 to 300

up to 17 side
Source

NWS weather chart nearest time of start

NWS weather chart or satellite information for day of interest

Nearest agricultural station or by direct observation

From textbook based on inspection

From textbook based on inspection or by calculation (see Snow, 1981)

USGS map

Users choice

100 to 300 on Users choice

up to 17
Users choice 
Table 3.A. (cont.)

\begin{tabular}{llll} 
Element & 2-D & 3-D & Source \\
\hline 5) $\begin{array}{l}\text { spacing of vertical } \\
\text { levels (m) }\end{array}$ & down to $5 \mathrm{~m}$ & down to $5 \mathrm{~m}$ & Users choice \\
6) time steps of model & 60 to $300 \quad 60$ to 300 & Users choice \\
$\begin{array}{l}\text { (sec) } \\
\text { 7) time of day at } \\
\text { which model is } \\
\text { started }\end{array}$ & open & open & Users choice \\
& & & \\
\hline
\end{tabular}


APPENDIX 4

NORMALIZING THE POWER ESTIMATES 
The potential wind power of a given site or location is based upon an estimate derived from model calculation for one, two or three dominant weather categories which represent $75 \%$ or more of the annual wind power potential. The reason for not performing model calculations for all situations is the cost of the model runs.

When 2-D calculations are used, many estimates can be made and little adjustment (normalizing) will be necessary. If 3-D calculations are made, the cost of the model runs is high. To obtain an annual power estimate, the percent of the year for which no estimates are made must be accounted for by normalizing the estimate to one.

To normalize, obtain the total percent occurrence of the dominant categories chosen from Table 1. For example for Region II, Table lb, Categories I, III and IV occur just over $85 \%$ of the year, each category occurring $17 \%, 26 \%$ and 428 of the time. Thus the weighting factors to be applied to obtain the annual power estimate are

$$
\begin{array}{ll}
\text { I } & 17 / 85=0.20 \\
\text { III } 26 / 85=0.31 \\
\text { IV } 42 / 85=0.49
\end{array}
$$

$$
1.00
$$

and the annual power distribution at $50 \mathrm{~m}$ would be

$$
\begin{array}{lll}
\text { I } & 547.2 \mathrm{~W} \mathrm{~m}^{-2}, 20 \% \text { of time } \\
\text { III } & 581.9 \mathrm{~W} \mathrm{~m}^{-2}, 318 \text { of time } \\
\text { IV } & 242.7 \mathrm{~W} \mathrm{~m}^{-2}, 498 \text { of time }
\end{array}
$$

for a mean annual wind power potential of just over $400 \mathrm{w} \mathrm{m}^{-2}$. 
PNL-3903

DISTRIBUTION

UC-60

No. of

No. of

Copies

Copies

\section{OFFSITE}

A. A. Churm

DOE Chicago Patent Group

9800 S. Cass Avenue

Argonne, IL 60439

5 D. F. Ancona

Department of Energy

Wind Energy Technology Division

1000 Independence Avenue

Forrestal Building

Room 5F059

Washington, DC 20585

5 C. I. Aspliden

Department of Energy

Wind Energy Technology Division

1000 Independence Avenue

Forrestall Building

Room 5F067

Washington, DC 20585

5 L. V. Divone

Department of Energy

Wind Energy Technology Division

1000 Independence Avenue

Forrestal Building

Room 5F059

Washington, DC 20585

5 G. P. Tennyson

Department of Energy

A] buquerque Operations Office

P. 0. Box 5400

Albuquerque, NM 87110

27 DOE Technical Information Center

T. G. Zambrano

AeroVironment, Inc.

145 Vista Avenue

Pasadena, CA 91107

Clarissa Quinlan

Alaska State Energy Dffice

338 Denali Street

Anchorage, AK 99501
Dr. K. C. Spengler

American Meteorological Society

45 Beacon Street

Boston, MA 02108

Tom Gray

American Wind Energy Association 1621 Connecticut Avenue, N.W. Wa shington, DC 20009

Richard Katzenberg 3100 Highland Place Washington, DC 20008

E. J. Warchol

Bonneville Power Administration P.0. Box 3621

Portland, OR 97208

S. J. Hightower

Bureau of Reclamation

Denver Federal Center

Building 67, Code 254

Denver, C0 80225

R. Nolan Clark

Department of Agriculture

Southwest Great Plains

Research Center.

Bushland, TX 79012

Jay Tappan

Department of Energy

State of Oregon

Labor and Industries Building

Room 111

Salem, OR 98310

Dr. Edgar DeMeo

Electric Power Research Institute 3412 Hillview Avenue

Palo Alto, CA 94303

Thomas R. Hiester

Flow Industries, Inc.

21414 68th Avenue, South

Kent, WA 98301 
Dr. Walter Frost

FWG Associates, Inc.

Route 2, Box 271-A

Tullahoma, TN 37388

R. C. Koch

GEOMET, Inc .

15 First Field Road

Gaithersburg, MD 20760

James D. West

HQ MAC/DEEE

Scott AFB, IL 62225

Gary G. Worley, Maj. USAF

HQ AF-ESC/RDVA

Tynda11 AFB, FL 32403

Gary L. Johnson

Electrical Engineering Department

Kansas State University

Manhattan, KS 66506

Abbey Page

Maine Office of Energy Resources

55 Capital

Augusta, ME 04330

Marlatt and Associates

3611 Richmond Drive

Fort Collins, CO 80521

V. F. Garrett

Montana Energy and MHD Research and Development Institute, Inc.

P.0. Box 3809

Butte, MT 59701

J. Konigsberg

Montana Energy Office

Capital Station

Helena, MT 59601
Phillip French

NASA Scientific and Technical Information Facility

P.0. Box 8757

Baltimore/Washington International Airport

Baltimore, MD 21240

Robert A. Wolf

NASA Scientific and Technical Information Facility

Mail Stop 500-202

Cleveland, $\mathrm{OH} 44135$

M. J. Changery

National Oceanic and Atmospheric Administration

National Climatic Center

Federal Building

Asheville, NC 28801

Matt Ginosar

Cal ifornia Energy Commission

1111 Howe Avenue, Mai1 Stop 66

Sacramento, CA 95825

John L. Zimmerman

New England Wind Energy Conversion Services

RDL Box 52E

Moretown, VT 05660

C. F. Chappe 11

Office of Weather Research and Modification

NOAA-ERL

Boulder, CO 80303

2

E. W. Hewson/J. E. Wade

Department of Atmospheric Sciences

Oregon State University

Corvallis, OR 97331 
No. of

Copies

3 Charles Toftoy

Project Manager

Raytheon Service Co.

Century Building, Rm. 826

234 Jefferson Davis Highway

Arlington, VA 22202

Terry J. Healy/C. Hansen

Rockwel1 International

Rocky Flats Plant

P.0. Box 464

Golden, CO 80401

E. Kadlec

Sandia Laboratories

Division 5443

P.0. Box 5800

Albuquerque, NM 87115

W. A. Tolbert, Capt. USAF

SERI Site Office/RTLO

1617 Cole Boulevard

Golden, C0 80401

Irvin Vas

Solar Energy Research Institute

1617 Cole Boulevard

Golden, C0 80401

Dr. C. M. Bhumralkar

Stanford Research

Institute, International

Menlo Park, CA 94025

Bruce Bailey

Atmospheric Sciences Department Center

State University of New York at Albany

Albany, NY 12222

N. E. Suhs

Tennessee Valley Authority

1360 Commerce Union Bank Building

Chattanooga, TN 37401
No. of

Copies

Dr. Thomas Schroeder

University of Hawai at Manoa

Department of Meteorology

2525 Correa Road

Honolulu, HI 96822

Dr. N. K. Wagner

Dept. of Civil Engineering

University of Texas

Austin, TX 78712

10 Dr. Michael Garstang

University of Virginia

Charlottesville, VA 22903

G. D. Thomann

Wichita State University

P.0. Box 44

Wichita, KS 67208

Farrell Smith Seiler

Wind Energy Report

Box 14, 104 S. Village Avenue

Rockville Centre, NY 11571

Earl Davis

Wind Farms, Ltd.

639 Front Street

San Francisco, CA 94111

Richard L. Berry

Atmospheric Environment

4905 Dufferin Street

Downsview, Ontario

M3H 5 T4

CANADA

Dr. Neil Cherry

Lincoln College

Canterbury, New Zealand 
No. of

Copies

\section{ONSITE}

DOE RICHLAND OPERATIONS OFFICE

P.0. Box 550

Richland, WA 99352

H. E. Ransom

$50 \quad$ Pacific Northwest Laboratory

Battelle Boulevard

Richland, WA 99352

W. R. Barchet (5)

J. C. Barnard

J. W. Buck

J. R. Connell

J. C. Doran

R. L. Drake

C. E. Elderkin

D. L. Elliott

W. J. Formica

R. L. George

D. L. Hadley

S. K. Heflick

V. K. Hopkins (15)

A. H. Miller

E. L. Owczarski

W. T. Pennel1

D. C. Powe 11

J. J. Praino

J. V. Ramsdell

D. S. Renné

J. M. Reeder

W. F. Sandusky

H. L. Wegley

L. L. Wendell

R. K. Woodruff

Technical Information - Library (5)

Publishing Coordination (2) 